\title{
Viriato y las ciudades de La Bética
}

\author{
Viriato and the towns of Baetica
}

\author{
MaURicio PAstor MuÑOz*
}

\begin{abstract}
RESUMEN
ABSTRACT

Viriato fue uno de los supervivientes de la matanza del pretor de la Hispania Ulterior, S. Sulpicius Galba, pero se ignora la fecha y el lugar de su nacimiento. La tradición histórica lo ha convertido sistemáticamente en un pastor de ganado, pero los trazos sobre su personalidad (sobriedad, energía, justicia, fidelidad) permiten considerarlo como un verdadero jefe militar y leader carismático de su pueblo. En este trabajo nos centramos en la conexión que tuvo Viriato con algunas ciudades de la Bética, concretamente con

Tucci (Martos, Jaén) y Urso (Osuna, Sevilla) durante las guerras lusitanas. Las fuentes principales son Apiano (Iber. 6075) y Diodoro de Sicilia (XXXIII).

PALABRAS CLAVE:

Viriato, Guerras lusitanas, Baetica, Hispania. Viriato was one of the survivors in
the slaughter of the praetor Hispania
Ulterior, S. Sulpicius Galba, but the
date and the place of his birth are
unknown. The historical tradition has
systematically turned him into a cattle
shepherd, but his personal features
(sobriety, energy, justice, loyalty) enable
us to consider him as a real military chief
and a charismatic leader for his people.
In this essay we focus on the connections
that Viriato had with some cities of
the Baetica: Tucci (Martos, Jaén) and
Urso (Osuna, Seville) specifically, during
the Lusitanian wars. The principal sources
are Apiano (Iber. 60-75) and Diodoro of
Sicily (XXXIII).

KEY WORDS:

Viriato, Lusitanian wars, Baetica, Hispania.
\end{abstract}

Mi excelente amigo, Federico Lara, fue quien me dio la idea y me ofreció la posibilidad de investigar y publicar la biografía de un personaje tan carismático en la Historia de España antigua como fue Viriato'. Es por ello por lo que, con motivo de

* Catedrático de Historia Antigua de la Universidad de Granada. Dirección: Urb. «Jardines de Rolando», 48, 18011-Granada; e-mail: mpastor@ugr.es; móvil: 629452927.

1 Cfr. PASTOR, M, Viriato, la lucha por la libertad, Ed. Alderabán, Madrid, 2000 (en portugués, Ed. Ésquilo, Lisboa, 2003; en francés, Ed. Pluvia Nocturna, París, 2009). Quiero expresar desde aquí mi 
su bien merecido homenaje, me ha parecido oportuno y conveniente presentar aquí algunos aspectos relacionados con la figura de Viriato que no fueron tratados in extenso en la biografía mencionada. Uno de ellos es su relación con algunas ciudades de la Bética.

En este trabajo nos centramos, concretamente, en Tucci (Martos, Jaén) ${ }^{2}$ y en Urso (Osuna, Sevilla) ${ }^{3}$, ambas importantes oppida del territorio bético en las que Viriato, como se deduce de las fuentes clásicas, acudió en ocasiones dejando constancia de su presencia. Sin duda, durante las guerras lusitanas, Viriato tuvo el control de muchas ciudades béticas, especialmente, del Alto Guadalquivir (Urso, Tribola, Itupci (Tucci), Obulcula, Baikor) sobre las que indudablemente debió ejercer un incuestionable liderazgo. Tucci y Urso fueron dos de ellas, aunque sus habitantes unas veces estaban a favor de los romanos y otras eran partidarias de Viriato.

Viriato, sin duda, es el máximo exponente de los jefes guerreros que gobernaron los oppida ibéricos en el mundo indígena hispano y del que mayor documentación tenemos ${ }^{4}$. Viriato es uno de los grandes héroes hispanos en los que más difícil resulta separar el punto donde termina la historia y donde empieza la leyenda ${ }^{5}$.

agradecimiento a Federico Lara por todo el trabajo que ha realizado en pro de la Historia Antigua y por brindarme su desinteresada amistad.

2 La localización de Tucci con Martos (Jaén) está perfectamente documentada en Plinio (Nat. Hist. 12, que la sitúa en el Conventus Astigitanus: Tucci quae cognominatur Augusta Gemella) y, sobre todo, en la epigrafía marteña: Colonia Augusta Gemella Tucci; Res Publica Tuccitanorum. Cfr. SERRANO DELGADO, J. M., "Colonia Augusta Gemella Tucci», Habis, 12, 1981, pp. 203-222; IDEM, «Sociedad y organización local de la colonia romana de Tucci», Actas del I Congreso Andaluz de Estudios Clásicos, Jaén, 1982, pp. 435-440; IDEM, La colonia romana de Tucci, Martos, 1987 pp. 30 ss.

3 Su localización en Osuna no ofrece ninguna duda. Cfr. al respecto, CHIC, G., «Una visión de Urso a través de las fuentes literarias antiguas", en F. Chaves Tristán (Ed.): Urso. A la búsqueda de su pasado, Osuna, 2002, pp. 188-213; PASTOR, M., "Osuna en las fuentes clásicas (Urso Genetiva Urbanorum)», en A. Engel y P. París, Una fortaleza ibérica en Osuna. Estudio preliminar y traducción de J. A. Pachón, M. Pastor y P. Rouillard, Coll. ARCHIVUM, 73, Granada, 1999, pp. LXXXV-CXXI; IDEM, «Viriato en el ámbito ursonense», Cuadernos de los amigos de los Museos de Osuna, 11, diciembre de 2009, Osuna, 2010, pp. 40-51.

${ }^{4}$ Los principales autores son: Apiano (Iber. 60-75) que se basa en Polibio y Diodoro de Sicilia (Biblioth. Hist. II, 33, 1, 7, 19 y 21a) que sigue a Posidonio (la descripción de Polibio se ha conservado en Estrabón (III, 3, 5) y la de Posidonio en Diodoro); lo citan también, Tito Livio (perioch. LII-LIV) y Dión Casio (frg. 73,77, 78); datos aislados se han conservado también en Floro, Orosio, Justino, Eutropio, Veleyo Patérculo, Cicerón, Aurelio Victor, Frontino y Silio Itálico. La tradición oral o escrita ibérica-lusitana no dejó nada escrito sobre su persona.

5 En otros trabajos he analizado detenidamente los diferentes aspectos de la vida de Viriato (origen, nombre, juventud, personalidad, estrategia, boda, reparto del botín, fama, etc.); también he analizado in extenso las guerras lusitanas (conquista y desarrollo), así como otros aspectos sobre los lusitanos (etnias, tribus, sociedad, economía, religión, etc.), a los que remito para su estudio. Cfr. PASTOR, M., Viriato. El héroe hispano que luchó por la libertad de su pueblo, Ed. La Esfera de los Libros, Madrid, 2004 (Ed. portuguesa, Lisboa, 2006); IDEM, «La figura de Viriato y su importancia en la sociedad lusitana», Sociedad y cultura en la Lusitania romana. IV Mesa Redonda Internacional, Mérida, 2000 pp. 35-52. En Viriato es muy dificil separar la historia real de la ficticia. Por esta razón, para la reconstrucción de la vida e historia de Viriato he utilizado los datos que trasmiten los analistas greco-romanos y las leyendas que ha generado la historiografía posterior, Vid, principalmente, mi trabajo PASTOR, M., «Viriato: historia compartida, mito disputado", en Jean-Gérard Gorges, José d'Encarnaçao, Trinidad Nogales y Antonio Carvalho (Eds.), Lusitana romana. Entre mito e a realidade. Actas da VI Mesa-Redonda Internacional sobre a Lusitania Romana, Cascais (Portugal), 2009, pp. 129-148. 
Veamos brevemente algunos datos históricos sobre el personaje. Sabemos que Viriato ${ }^{6}$ vivió a mediados del siglo II a.C. en la provincia hispana que los romanos denominaron Lusitania, cuya delimitación precisa es aún, hoy día, problemática, pero que abarcaba territorios portugueses y españoles ${ }^{7}$, de aquí que historiadores de ambos países se hayan disputado, desde siempre, su lugar de nacimiento, dando origen a una larga polémica nacionalista, tan absurda como estéril, toda vez que, por entonces, ni España, ni Portugal existían como estados independientes ${ }^{8}$.

Viriato aparece en la documentación histórica durante las guerras lusitanas y celtibéricas que Roma sostuvo en Hispania ${ }^{9}$, concretamente, en las campañas contra Cayo Vetilio, cuando los lusitanos lo eligen como jefe. Los acontecimientos ocurridos los cuenta Apiano:

«No mucho después, cuantos escaparon a la perfidia de Lúculo y Galba, reunidos hasta 10.000 invadieron la Turdetania. Contra ellos se dirigió Cayo Vetilio, lle-

${ }^{6}$ El nomen Viriathus deriva del ibérico viria, que significa «pulsera», «brazalete». No tiene nada que ver con el término vires = «hombre», "varón», aunque tenga la misma raíz. Viriathus es similar a Torquatus. Viriathus sería el portador de los viria (brazaletes) en el brazo y Torquatus el que lleva torques (collar) en el cuello. El nombre es más céltico que ibérico como demuestran los topónimos y las inscripciones aparecidas en las provincias del Danubio, la Galia Cisalpina y la Provenza y es frecuente en Lusitania septentrional y meridional, donde había población celta. Según Estrabón y Diodoro, los celtas apreciaban mucho los brazaletes de plata y oro. Las estatuas de los guerreros galaico-lusitanos aparecen con estos adornos. También en Portugal se han hallado con frecuencia esculturas de estatuas con brazaletes.

7 La descripción más completa de Lusitania la ofrece Estrabón (III, 3, 3-4). Cfr. SCHULTEN, A., Fontes Hispaniae Antiquae, VI, Estrabón. Geografía de Iberia, Barcelona, 1952; BLÁZQUEZ, J. M., «La Iberia de Estrabón» Hispania Antiqua, I, 1971, pp. 7 ss.; CRUZ ANDREOTTI, G. (Ed.), Estrabón e Iberia: Nuevas perspectivas de estudio, Málaga, 1999, pp. 121 ss. El territorio lusitano estaba integrado por diversos pueblos, como los célticos, túrdulos, vetones, paesuros, lusitanos propiamente dichos, e incluso parte de los galaicos, cuyas diferencias y conexiones entre sí no siempre están claras en las fuentes clásicas. Hoy por hoy es prácticamente imposible diferenciar lo lusitano como una unidad étnica y geográfica distinta de las otras regiones de la Península Ibérica.; vid. RODRÍGUEZ DÍAZ, A., «Territorio y etnias prerromanas en el Guadiana Medio: Aproximación arqueológica a la Beturia Túrdula», Celtas y Turdulos: La Beturia, Mérida, 1995, pp. 205-254; PÉREZ VILATELA, L., Lusitania. Historia y Etnología, Madrid, 2000.

8 Cfr. principalmente, PASTOR, M., Viriato. El héroe hispano.... Op. cit. pp. 213 ss.; IDEM, «Viriato, historia compartida, mito disputado», Art. Cit. pp. 128 ss.; vid. también, GUERRA, A. y FABIÂO, C., «Viriato: Genealogía de um mito», Penélope, 8, 1992, pp. 9-23; IDEM, «Viriato: em torno da iconografia de um mito", Mito e símbolo na historia de Portugal e do Brasil, Actas dos IV Cursos Internacionais de Verâo de Cascais (7-12 de Julho de 1997), Cascais, 1998, pp. 33-79.

9 Para el desarrollo de las guerras y el análisis de las fuentes, vid. principalmente: PASTOR, M., Viriato. El héroe hispano... Op. cit. pp. 153-194; vid. también, SCHULTEN, A., «Viriathus», Neue Jahrbücher», 39, Heildelberg, 1917, pp. 209-237 (= «Viriato», Boletín de la Biblioteca Menéndez y Pelayo, II, Santander, 1920, 1-3, pp. 126-149 y 1, 4, 5 y 6, pp. 272-281); SIMON, H., Roms Kriege in Spanien, 154133 v. Chr., Frakfurt del Meno, 1962; pp. 66 ss., 89 ss. y 116 ss.; BOSCH GIMPERA, P. y AGUADO BLEYE, P., «La conquista de España por Roma (218 a 19 a. C.), Cap. III, «Las guerras de lusitanos y celtíberos contra Roma. Primer período (154 a 143): Viriato», en Historia de España de R. Menéndez Pidal, Madrid, 1962, pp. 116 ss.; GUNDEL, H. G., «Viriato, lusitano, caudillo en las luchas contra los romanos, 147-134 a. C.», Caesaraugusta, 31-32, 1968, pp. 179 ss.; MONTENEGRO, A., «La conquista de Hispania por Roma (218-19 a.C.), Cap. III: las guerras de Lusitania (155-138) y Celtiberia (153-133), en Historia de España de R. Menéndez Pidal, II, 1: La conquista y la explotación económica, Madrid, 1982, pp. 89 ss.; SALINAS, M., «Las guerras celtibéricas y la conquista romana del valle del Duero», Villes, territoirers dans le bassin du Douro à l'époque romaine, Bordeaux, 2007, pp. 27-42. 
gado de Roma con algunas tropas nuevas a las que juntó las que había en Hispania, unos 10.000 en total. Sorprendiendo a los lusitanos en sus correrías, mató a muchos y obligó a los restantes a refugiarse en un lugar, provocándoles una situación difícil, pues quedándose allí sucumbirían al hambre y, si salían, a los romanos. En vista de esto, los lusitanos enviaron una legación con ramos de olivo a Vetilio pidiéndoles tierras para establecerse y prometiéndole permanecer sometidos al pueblo romano en adelante. Vetilio prometió darles tierras y se disponía a formalizar el pacto cuando Viriato, que había logrado escapar de la crueldad de Galba y se hallaba entre ellos, les puso en guardia contra la perfidia de los romanos, recordándoles cuántas veces les habían atacado faltando a sus juramentos y cómo aquel ejército no era otra cosa que los restos escapados a los perjurios de Galba y Lúculo, diciéndoles que no desesperasen de salir de aquella situación si querían obedecerle ${ }^{10}$.

Su carisma, su prestigio, su oratoria y su experiencia fueron las virtudes que le llevaron al liderazgo entre sus compatriotas. Según Apiano, le nombraron jefe o caudillo (hegemón = «conductor de grupos») por ser el más cualificado para asumir el mando militar del grupo:

«Animados y llenos de moral, eligieron a Viriato como jefe. Éste colocó a todos los hombres de frente, como en disposición de combate, ordenándoles que cuando montaran a caballo, se dispersasen en todas las direcciones y huyesen como pudieran por caminos diversos hasta la ciudad de Tribola y que allí le esperasen. Por otra parte, seleccionó a un millar de jinetes para que quedasen junto a él. Dispuestas estas cosas, Viriato montó a caballo y los lusitanos se dieron a la fuga. Vetilio no se molestó en perseguir a quienes huían en dispersión, sino que se dirigió contra Viriato, que permanecía en guardia y atento a los acontecimientos para entablar combate con él. Pero Viriato con sus velocísimos caballos, pasó todo aquel día y el siguiente corriendo por la llanura, hostigándole, replegándose, haciéndole frente de nuevo y atacándole» ${ }^{11}$.

Sabemos también que Viriato fue uno de los supervivientes de la matanza del pretor Galba, pero ignoramos la fecha y el lugar de su nacimiento, así como el nombre de sus padres, su infancia y su juventud. La tradición histórica sistemáticamente lo ha convertido en un pastor de ganado, pero los trazos sobre su personalidad recogidos en los autores antiguos, que lo presentan como un hombre sobrio, enérgico, justo en el reparto del botín y fiel a la palabra dada, con absoluto desprecio por el lujo y las comodidades, y un excelente estratega, permiten considerarlo como un verdadero político, jefe militar indiscutible de los lusitanos y defensor de su libertad, y no en un rudo pastor de las montañas lusitanas ${ }^{12}$.

10 Apiano, Iber. 6, 11, 61. Vid. GÓMEZ ESPELOSíN, F. J., Apiano: Sobre Iberia y Aníbal, Madrid, 1993; vid. también, SANCHO, A., «Consideraciones en torno al testimonio de Apiano y Diodoro como fuente para las guerras celtíbero-lusitanas», Actas del VI Congreso Español de Estudios Clásicos, II, 1983, pp. 19 ss.

11 Apiano, Iber. 6, 11, 62.

12 PASTOR, M., Viriato. El héroe hispano... Op. cit. pp. 37-60; vid. también, GARCíA MORENO, L. A., «Infancia, juventud y primeras aventuras de Viriato, caudillo lusitano», De Gerión a César. Estudios históricos y filológicos de la España indígena y romano-republicana, Alcalá de Henares, 2001, pp. 139152; PÉREZ VILATELA, L., Lusitania. Historia y Etnología; Madrid, 2000, pp. 259 ss.; LÓPEZ MELERO, 
Diodoro de Sicilia, siguiendo a Posidonio, dice de él:

«El lusitano Viriato, de oscuro linaje, según algunos, pero famosísimo por sus hazañas, ya que de pastor se hizo bandolero y después general, era por sus condiciones naturales y por los ejercicios que hacía extremadamente rápido en la persecución y en la huida y muy fuerte en la lucha a pie firme. Los manjares comunes y una bebida sin refinamientos eran los que con mayor placer tomaba: pasó la mayor parte de su vida al aire libre, y se contentó siempre con los lechos que la misma naturaleza le ofrecía. Por esta causa fue superior a toda clase de cansancios e inclemencias, nunca sufrió del hambre, ni se lamentó de ninguna contrariedad, sabiendo sacar provecho de todas las circunstancias desfavorables. Dotado tanto por la naturaleza como por su cuidado de estas cualidades físicas, sobresalía en mucho más por las cualidades de su espíritu. Era rápido en comprender y en ejecutar lo debido, viendo a un tiempo lo que debía hacerse y la oportunidad para ejecutarlo, capaz también de fingir conocimiento de lo más recóndito e ignorancia de lo más evidente. Tanto en el mando como en la obediencia aparecía siempre el mismo, ni modesto ni soberbio; sino que por humildad de su origen y por el prestigio de su poder consiguió no ser ni inferior ni superior a nadie. En suma, no emprendía la guerra ni por avaricia, ni por amor al mando, ni por cólera, sino que la hacía por ella misma, y es por esto sobre todo que fue temido por belicoso y conocedor del arte bélico» ${ }^{13}$.

\section{De manera similar se expresa Dión Casio:}

«Viriato fue un lusitano de origen oscuro, según algunos, que logró gran renombre con sus hazañas, ya que de pastor llegó a ser ladrón y más tarde incluso general. Tenía buenas condiciones naturales y también se entrenó para ser muy ágil tanto en la persecución como en la huida y tenía una gran resistencia en el combate directo. Estaba satisfecho con cualquier comida que tuviese y cualquier bebida le satisfacía; la mayor parte de su vida la pasó al raso y estaba satisfecho con lo que la naturaleza le daba. En consecuencia, era indiferente al calor o al frío, y nunca se vio molesto por el hambre o por cualquier otra privación; pues satisfacía todas sus necesidades con cualquier cosa que encontrase a mano, como si fuese la mejor. Además de poseer un cuerpo que resultaba de la naturaleza y el entrenamiento, era todavía mejor en sus poderes mentales. Era rápido para planear y llevar a término cualquier cosa que fuese necesaria, pues no sólo sabía qué se debía hacer, sino que también entendía cuál era el momento oportuno para hacerlo; y también era inteligente cuando fingía ignorar los hechos más obvios y conocer los secretos más ocultos.... En resumen, él llevaba adelante la guerra no por la búsqueda de ganancias personales, o de poder, o movido por la ira, sino por el placer de las hazañas de la guerra en sí mismas, púes se le consideraba a la vez un amante de la guerra y un señor de la guerra» ${ }^{14}$.

R., «Viriatus Hispaniae Romulus», Espacio, Tiempo y Forma, II, Historia Antigua, 1988, pp. 247 ss.; GUERRA, A. y FABIÂO, C., «Viriato: genealogía de un mito», art. cit. pp. 12 ss.; ALVAR, J., «Héroes ajenos: Aníbal y Viriato", Héroes y Antihéroes en la Antigüedad Clásica, Madrid, 1997, pp. 137 ss.; GARCíA QUINTELA, M. V., Mitología y mitos de la Hispania prerromana, III, Madrid, 1999, pp. 213 ss.

13 Diodoro, Bib.Hist. XXXIII, 1-6; cfr. TORRES ESBARRANCH, J. J., Diodoro de Sicilia. Biblioteca Histórica. Libros IV-VIII. Ed. Gredos, Madrid, 1993; MUÑOZ MARTíN, M. N., España en la Biblioteca histórica de Diodoro Sículo. Introducción, traducción y notas, Granada, 1976.

${ }^{14}$ Dión Casio, 73,77, 78; cfr. SÁNCHEZ MERINO, E., Historias romanas, Madrid, 1989: MILLAR, F., A Study of Cassius Dio, Oxford, 1964. 
Viriato se presenta en ambos pasajes como un hombre, cuya fortaleza y virtud han surgido de su vivencia juvenil en un estado de naturaleza. Vivir en un medio hostil, probablemente en zona montaña, entre piedras y animales, le va a dotar de una gran capacidad de sufrimiento y de gran agilidad física, expresadas en una fundamental autarquía con desprecio de las riquezas y los lujos de la vida «civilizada». Una vez que se convirtió en jefe y general de los lusitanos, Viriato se caracterizó por su extremada justicia para con sus compañeros, compartiendo siempre con ellos todos los bienes por igual. Viriato poseía también una sabiduría natural innata, de enorme valor en la toma de decisiones, a pesar de no haber tenido una educación reglada. Sus razonamientos solían ser muy acertados «como correspondía a su naturaleza no torcida ni educada por ningún maestro». Ahora bien, desconocemos cuánto había de realidad en todo esto. No lo sabemos, pero son datos sumamente reveladores.

A partir del 150 a.C. Viriato ya estaba al frente de las tropas lusitanas y preparaba su ejército para la gran insurrección contra Roma ${ }^{15}$. Con anterioridad, el pretor de Hispania Ulterior, Servio Sulpicio Galba, que se había refugiado en Carmona tras una dura campaña contra los lusitanos en la que había perdido 7.000 hombres, hizo propuestas de paz con la promesa de ofrecer lotes de tierra a quienes abandonasen las armas. Pero cuando se habían reunido más de 30.000 hombres dispuestos a vivir en paz con Roma, los encerró en tres campamentos y, una vez desarmados, ordenó la matanza a discreción. Unos 9.000 fueron asesinados y 20.000 fueron hechos prisioneros para ser vendidos como esclavos en la Galia; tan sólo 1.000 lograron escapar a la masacre, entre ellos, Viriato. En la propia Roma, muchos senadores clamaban indignados y el propio Catón propuso la liberación de los esclavos y la creación de un tribunal para investigar el comportamiento del pretor. Galba fue juzgado haciéndose cargo él mismo de su defensa. Para mover la compasión de los jueces acudió al Senado con sus dos hijos y un tercero del que era tutor, pidiendo que el pueblo romano los protegiese si a él le consideraban merecedor de la muerte. Al principio, el Senado se negaba a absolverle de sus delitos, pero cuando se decidió a entregar una gran parte del dinero robado en Hispania, el Senado le absolvió. El dinero pudo más que la compasión. Tan grande era el poder del dinero que cinco años más tarde Galba sería nombrado cónsul.

Viriato comenzó así a convertirse en el verdadero protagonista de las guerras entre lusitanos y romanos y comenzó a gestarse su leyenda como estratega. Su nombre sonaba repetidamente en los discursos de los oradores del Senado romano. Pronto la revuelta lusitana adquirió una nueva dimensión ${ }^{16}$.

Y es, a partir de este momento, cuando las ciudades béticas, Tucci y Urso, entran en la esfera de Viriato. Probablemente Viriato llegó hasta ellas o a sus inme-

15 Cfr. PÉREZ VILATELA, L., «Notas sobre la jefatura de Viriato en relación con la Ulterior», Archivo de Prehistoria Levantina, XIX, 1989, pp. 191-204; PASTOR, M., Viriato. El héroe hispano... Op. cit. pp. 79 ss.

${ }_{16}$ Cfr. principalmente, PASTOR, M.: Viriato. El héroe hispano... Op. cit. pp. 153-194. 
diaciones, puesto que en el 147 a.C., al frente de unos 10.000 lusitanos penetró en Turdetania por el valle del Guadalquivir y sus tropas fueron cercadas junto a Urso por las del pretor Cayo Vetilio, que había llegado hacía poco a la Ulterior. De nuevo se entablaron negociaciones. Vetilio les ofrecía tierras de cultivo si se rendían y entregaban las armas. Fue entonces, como hemos señalado, cuando se impuso la personalidad de Viriato recordando a sus compatriotas que los romanos no cumplían nunca sus pactos, ni sus promesas. Ello motivó la suspensión de las negociaciones que, posiblemente, se debieron realizar en Urso o en su entorno.

Viriato fue elegido jefe del ejército y elaboró un plan para eludir el cerco: ordenó que sólo 1000 jinetes se quedasen con él y que los demás huyeran en direcciones distintas hasta reunirse todos en la localidad de Tríbola a la espera de su llegada. El plan resultó eficaz. Los romanos, sorprendidos, se desordenaron y el frente quedó roto. Vetilio atacó únicamente a Viriato y a sus jinetes como él había planeado, pero Viriato escapó por la noche y marchó hacia Tribola para reunirse con los suyos. El pretor Vetilio, burlado, le siguió lentamente con sus pesadas legiones y su pésima caballería. Viriato reorganizó sus tropas y preparó la emboscada definitiva. El desastre romano fue total; en la emboscada murieron más de 4.000 soldados romanos, entre ellos su propio general, a quien un soldado de Viriato atravesó con su lanza, sin saber siquiera a quien estaba matando, pero al que denominó «viejo gordo e inútil»; el resto, unos 6.000 soldados, se refugiaron en Carteia. Un ejército de 5.000 mercenarios de las tribus de los bellos y titos, aliados de Roma, y enviados contra Viriato por el pretor Cayo Plaucio, sucesor de Vetilio, fue también aniquilado. Igual suerte corrieron los pretores de Hispania Citerior, Claudio Unimano y $\mathrm{C}$. Nigidio, a los que Viriato derrotó y arrebató sus estandartes colocándolos en las montañas como trofeos de guerra ${ }^{17}$.

La muerte de Vetilio y las derrotas de Plaucio, Unimano y Nigidio provocaron la dispersión del ejército romano y permitieron a Viriato recorrer toda la Bética y parte de la Carpetania sin oposición. Además, el éxito hizo recuperar la moral de los lusitanos hasta el punto que sirvió de acicate para una resistencia generalizada contra Roma. Viriato sería el jefe indiscutible de los lusitanos y durante más de ocho años se convirtió en el «terror» de Roma ${ }^{18}$. Su máximo exponente era la guerra de guerrillas, con la que se aprovechaba al máximo el conocimiento del terreno y hacía inútil la fuerza ordenada de las legiones romanas.

La táctica militar utilizada en este tipo de guerra variaba según las circunstancias. Unas veces, consistía en cansar al adversario, impidiéndole el abastecimiento; y otras, trataba de eliminarlo mediante una emboscada o una huida aparente. Casi nunca se presentaban batallas en formación. Esto se explica, no solo

17 PASTOR, M., Viriato. El héroe hispano... Op. cit. pp. 153-194.

18 Es difícil calcular con exactitud la duración de su mandato, ya que las fuentes clásicas no son claras al respecto. Así, mientras que para Apiano son 8 años (147-139 a.C.), para Justino son 10, para Diodoro de Sicilia, 11, para Tito Livio y sus comentaristas Floro, Orosio y Eutropio son 14 y, finalmente, para Veleyo Patérculo son 20 años. Esta disparidad radica en considerarlo jefe desde el comienzo de la guerra (153 a.C.), o desde la matanza de Galba (150). A partir de Schulten se acepta la afirmación de Apiano (8 años). 
por la escasez de tropas, sino también por la inferioridad de las armas de sus soldados a la de los legionarios romanos.

Viriato no se proponía la conquista permanente del territorio enemigo, sino su saqueo sistemático. Por eso, la rapidez y la sorpresa son esenciales en este tipo de guerras. Viriato inquietaba y aniquilaba a los romanos por medio del ataque disperso empleando a la vez soldados de infantería y de caballería. Esta maniobra militar la denominaban los romanos: concursare, el constante pegar y rebotar. Para desarrollar su estrategia Viriato disponía de un importante ejército formado por guerreros de diferentes pueblos, entre ellos los tuccitanos, preparados para este tipo de guerras. A pesar de su diversidad étnica, Viriato consigue en este ejército, a base de una férrea disciplina y un adiestramiento apropiado, una excelente preparación militar. Pero a estos guerreros, ágiles, infatigables y valientes, inferiores a los legionarios romanos, les faltaban otras cualidades, como la disciplina y la perseverancia, sin las cuales es imposible el triunfo.

El ejército de Viriato disponía también de un armamento apropiado para este tipo de guerras. El armamento ibero-lusitano, que conocemos bien gracias a los textos de Diodoro ${ }^{19}$ y de Estrabón ${ }^{20}$, a la arqueología y a las esculturas de los guerreros de Osuna. Constaba de un escudo pequeño y redondo, muy apropiado para los combates cuerpo a cuerpo, una espada y un cuchillo, una larga lanza de hierro y un casco de cimera con crines volantes y corazas de lino. Muy pocos usaban gorros de cuero o cascos de metal y eran raros los que llevaban casacas o glebas metálicas. Se adornaban con collares y brazaletes, torques y viria, como los encontrados en Galicia y norte de Portugal. Para luchar de lejos usaban dardos y jabalinas que lanzaban con gran destreza y a gran distancia. Las lanzas eran de hierro (soliferreum), o de madera con la punta de hierro. Para la lucha cuerpo a cuerpo usaban el puñal, la espada y el sable ibérico de doble curvatura (falcata), que ha aparecido con profusión en las excavaciones arqueológicas.

La personalidad de Viriato destaca también en la forma de distribución y apropiación del botín. Son los jefes quienes controlan los botines y tributos obtenidos por la guerra ${ }^{21}$. La actitud de Viriato en el reparto del botín está reflejada en los textos clásicos que aluden a los repartos de botines y de regalos por parte de Viriato, al que consideran justo, equitativo y generoso, siguiendo el paradigma del buen salvaje pregonado por la doctrina estoica. Diodoro se refiere a estos repartos en algunos pasajes de su obra:

19 Diodoro, Bibl. Hist. II, XXXIII, 7, 1-6.

20 Estrabón, Geogr. 139, 152; cfr. SCHULTEN, A., Estrabón, Geografía de Iberia. Fontes Hispaniae Antiquae, VI, Barcelona, 1952; MEANA, M. J. y PIÑERO, F., Estrabón. Geografía (Hispania y Galia), Barcelona, 1995.

${ }_{21}$ SÁNCHEZ MORENO, E., «Algunas notas sobre la guerra como estrategia de interacción social en la Hispania prerromana: Viriato, jefe redistributivo» (Parte I) Habis, 32, 2001, pp. 149-169; (Parte II), Habis, 33, 2002, pp. 169-202; IDEM, «El botín de Viriato: guerra y sociedad en Lusitania», Boletín de la Asociación Española de Arqueología. Homenaje a la Dra. Encarnación Ruano, 42, 2002-03, pp. 305-331; IDEM, «Ex pastore latro, ex latrone dux...Medioambiente, guerra y poder en el Occidente de Iberia», War and Territory in the Roman World (Actas de la mesa redonda guerra i territori en el mon romá: una discussió historicoarqueologica (Bellaterra, 8-9 marzo, 2005), Barcelona, 2008, pp. 55-79. 
«En el reparto del botín era justiciero, y distinguía con regalos a los que destacaban por su valor... Viriato, el jefe de ladrones lusitano, era justo en el reparto del botín: basaba sus recompensas en el mérito y hacía regalos especiales a aquellos de sus hombres que se distinguían por su valor, además no cogía para su uso particular lo que pertenecía a la reserva común. Debido a ello, los lusitanos le seguían de buen grado a la batalla y lo honraban como su benefactor y salvador común... en el reparto del botín no tomaba nunca una parte mejor que los otros; y de lo que tomaba, u obsequiaba a los que más se distinguían o subvenía a las necesidades de los soldados»22.

En el mismo sentido escriben Apiano y Cicerón:

«Tanta fue la añoranza que Viriato dejó tras de sí, el que más dotes de mando había tenido entre los bárbaros y el más atrevido ante todo por delante de todos y el más presto al reparto a la hora del botín. Pues nunca aceptó tomar una parte mayor a pesar de que continuamente le animaban a ello; e incluso lo que tomaba se lo entregaba a quienes más habían destacado en la lucha. Por esto, un asunto complicado y no fácilmente conseguido por ningún otro de los generales: durante los ocho años de esta guerra un ejército constituido de elementos heterogéneos nunca se le rebeló y siempre fue sumiso y el más resuelto a la hora del peligro» ${ }^{23}$,

«y así, por su equidad en repartir el botín, obtuvieron un gran poder no sólo Bardilis, bandolero ilirio, sino también y mucho mayor el lusitano Viriato „24.

Otro aspecto a señalar se refiere a la manipulación que hace un jefe de los botines adquiridos utilizándolos para ganarse la fidelidad de sus ejércitos y la adhesión de sus clientes. Las fuentes reiteran que Viriato distinguía a sus partidarios con regalos y presentes. Los textos hablan de este intercambio de regalos, sobre todo, de bienes de prestigio (brazaletes, torques, caballos e incluso mujeres). Elementos que han sido corroborados también por los hallazgos arqueológicos (armas de guerreros, cerámicas lujosas de importación, bocados de caballo, etc.), que constituían el ajuar funerario de las elites rectoras. Así se consolidaba el prestigio y la autoridad del jefe, siguiendo la máxima de «cuánto más regalas, mayor respaldo y poder obtienes». Y más aún, si los regalos son exóticos y conseguidos en campañas militares externas, como los obtenidos por Viriato. Muchos de estos objetos, como los brazaletes, pulseras y torques, con un marcado carácter político-social, han aparecido entre los ajuares guerreros de las necrópolis íbero-lusitanas y aparecen representados en las esculturas de los guerreros galaico-lusitanos ${ }^{25}$.

Pero volvamos de nuevo al desarrollo de las guerras contra Viriato para acercarnos a las referencias que tenemos sobre Tucci, y Urso, aunque es práctica-

22 Diodoro, Bibl. Hist. II, XXXIII, 1-6.

${ }^{23}$ Apiano, Iber. $6,11,75$.

24 Cicerón, De Offic. 2, 40. Cfr. GUILLÉN, J., Sobre los deberes, Madrid, 1989.

25 Sobre estas piezas, cfr. principalmente, BLANCO FREIJEIRO, A., «Origen y relaciones de la orfebrería castreña», Cuadernos de Estudios Gallegos, 12, 1957, pp. 5-28, 137-157, 267-300; LÓPEZ CUEVILLAS, F., La civilización céltica en Galicia, Madrid, 1988, pp. 173-226; ELUERE, Ch., L'or des Celtes, Friburgo, 1987; PÉREZ OUTEIRIÑO, «Orfebrería castreña», El oro en la España prerromana. Revista de Arqueología, Madrid, 1989; CASTRO PÉREZ, L., Los torques de los dioses y de los hombres, La Coruña, 1992. 
mente imposible reconstruir completamente su evolución histórica, pues son muy escasos los datos que hacen referencia a la estancia o paso de Viriato por estas ciudades o pos sus alrededores ${ }^{26}$.

Apiano cita ambas ciudades y aporta algunos datos interesantes:

"Cuando se supo esto en Roma, enviaron a Hispania a Fabio Máximo Emiliano, hijo de Emilio Paulo, el vencedor de Perseo, rey de Macedonia, encargándole de la leva de un ejército. Pero él, viendo que la ciudad estaba exhausta por las conquistas de Cartago y de Grecia, y por la conclusión de la tercera guerra de Macedonia, para no utilizar más a los que regresaban de estas campañas, reclutó dos legiones de jóvenes bisoños, que no habían tomado parte aún en ninguna guerra. $Y$, habiendo solicitado de los aliados otros refuerzos, con un ejército de quince mil de a pie, y unos dos mil de a caballo, llegó a Urso, ciudad de Hispania. Desde aquí, no queriendo abrir las hostilidades hasta tener la tropa bien entrenada, navegó hasta Gades, para hacer un sacrificio a Hércules. Entretanto Viriato, cayendo sobre unos soldados que habían salido para hacer leña, mató a muchos y llenó de pavor a los demás; y como el que mandaba estas fuerzas las formase en orden de batalla, de nuevo las derrotó Viriato, tomándoles mucho botín. Regresado Máximo, continuamente le provocaba a combate con sus tropas formadas; pero Máximo no quería exponer todas sus fuerzas, a las que instruía aún; pero, con escaramuzas sostenidas con pequeños destacamentos, exploraba las fuerzas del enemigo, y fortalecía el ánimo de los suyos. Cuando salían los convoyes de aprovisionamiento, rodeaba siempre de una escolta armada a los que iban sin armas, y él mismo solía seguirles con una tropa de jinetes; como lo había aprendido de su padre Paulo, bajo el cual había combatido en Macedonia. Pasado el invierno, y bien instruido ya el ejército, consiguió ser el segundo en poner en fuga a Viriato, quien luchó bravamente, y, de dos ciudades de éste, saqueó una e incendió la otra; y, acosando al enemigo hasta un castillo llamado Baicor, le mató muchos hombres. Pasó el invierno en Corduba, a los dos años ya de dirigir esta guerra. Y Emiliano, después de haber realizado estas campañas, partió para Roma, recibiendo el mando Quinto Pompeyo Aulo....»

«Después de esto, Viriato no despreciaba ya al enemigo como antes y obligó a sublevarse contra los romanos a los arevacos, titos y belos que eran los pueblos más belicosos. Y éstos sostuvieron por su cuenta otra guerra que recibió el nombre de «numantina» por una de sus ciudades y fue larga y penosa en grado sumo para los romanos. Yo agruparé también lo concerniente a esta guerra en una narración continuada después de los hechos de Viriato. Este último tuvo un enfrentamiento con Quintio, otro general romano, en la otra parte de lberia y, al ser derrotado, se retiró de nuevo al monte de Venus. Desde allí hizo de nuevo una salida, dio muerte a mil soldados de Quintio y le arrebató algunas enseñas. Al resto lo persiguió hasta su campamento y expulsó a la guarnición de Itucci. También devastó el país de los bastitanos, sin que Quintio acudiera en auxilio de éstos a causa de su cobardía e inexperiencia. Por el contrario, estaba invernando en Córduba desde mi-

${ }^{26}$ La localización de Tucci con la actual Martos (Jaén) está perfectamente documentada por Plinio (N.H. III, 12, que la sitúa en el Conventos Astigitanus como Tucci quae cognominatur Augusta Gemella) y, sobre todo, por la epigrafía aparecida en la localidad que la cita como Colonia Augusta Gemella Tucci, o como Res Publica Tuccitanorum. Cfr. principalmente, SERRANO DELGADO, J. M.: «Colonia Augusta Gemella Tucci», Habis, 12, 1981, pp. 203-222; IDEM, «Sociedad y organización local de la colonia romana de Tucci», Actas del I Congreso Andaluz de Estudios Clásicos, Jaén, 1982, pp. 435-440; IDEM, La colonia romana de Tucci, Martos, 1987 pp. 30 ss. 
tad del otoño y, con frecuencia, enviaba contra él a Gayo Marcio, un ibero de la ciudad de Itálica»...

«Al año siguiente, Fabio Máximo Serviliano, el hermano de Emiliano, llegó como sucesor de Quintio en el mando, con otras dos legiones y algunos aliados. En total sus fuerzas sumaban unos 18.000 infantes y 1.600 jinetes. Después de escribir cartas a Micipsa, el rey de los númidas, para que le enviase elefantes lo más pronto posible, se apresuró hacia Itucci llevando el ejército por secciones. Al atacarle Viriato con 6.000 hombres en medio de un griterío y clamores a la usanza bárbara y con largas cabelleras que agitaban en los combates ante los enemigos, no se amilanó, sino que le hizo frente con bravura y logró rechazarlo sin que hubiera conseguido su propósito. Después que le llegó el resto del ejército y enviaron desde África 10 elefantes y 300 jinetes, estableció un gran campamento y avanzó al encuentro de Viriato, y tras ponerlo en fuga, emprendió su persecución. Pero, como ésta se hizo en medio del desorden, Viriato, al percatarse de ello durante su huida, dio media vuelta y mató a tres mil romanos. Al resto los llevó acorralados hasta su campamento y los atacó también. Sólo unos pocos le opusieron resistencia a dura penas alrededor de las puertas, pero la mayoría se precipitó en el interior de las tiendas a causa del miedo y tuvieron que ser sacados con dificultad por el general y los tribunos. En esta ocasión destacó en especial Fanio, el cuñado de Lelio, y la proximidad de la noche contribuyó a la salvación de los romanos. Pero Viriato, atacando con frecuencia durante la noche, así como a la hora de la canícula, y presentándose cuando menos se le esperaba, acosaba a los enemigos con la infantería ligera y sus caballos, mucho más veloces, hasta que obligó a Serviliano a regresar a $\mid t_{t u c c{ }^{27}}$.

Este largo texto nos informa de que en el año 145 los romanos enviaron a la provincia Hispania Ulterior al cónsul Q. Fabio Máximo Emiliano, hijo de Emilio Paulo, para luchar contra los lusitanos ${ }^{28}$. El año anterior Viriato había ascendido hacia el Norte pasando posiblemente por Urso y Tucci y se dedicó a saquear Carpetania antes de volver sobre el valle del Genil, donde lo vemos actuar en los dos años siguientes, contando, sin duda, con las simpatías de la población de la zona. Por sus victorias, Viriato se había convertido en «dueño y señor de la Ulterior», lo que le permitía dominar y saquear con sus tropas las tierras de la Beturia y todo el fértil valle del Guadalquivir. Pero, al año siguiente, una ofensiva romana arrebató a Viriato la ciudad de Baikor, que suele identificarse con Baecula (Bailén), con lo cual los romanos recuperaban paulatinamente el valle del Guadalquivir.

Pero los éxitos romanos fueron pasajeros. Los sucesores de Fabio Máximo Emiliano, Q. Pompeyo y A. Quintio, fueron derrotados por Viriato, que se apoderó nuevamente de Itucci, derrotando a las tropas romanas con la ayuda de las tribus celtíberas de arévacos, bellos y titos, que habían defeccionado de Roma y se habían sumado a su causa ${ }^{29}$. A continuación, se dedicó a saquear la Bastetania. En

27 Apiano, Iber. 6, 11, 65-68.

${ }_{28}$ Cfr. ASTIN, A. E., Scipio Aemilianus, Oxford, 1967; CHIC, G., "Consideraciones sobre las incursiones lusitanas en Andalucía», Gades, 5, 1980, pp. 15-25; PÉREZ VILATELA, L., «Notas sobre la jefatura de Viriato en relación con la Ulterior», Art. cit. pp. 191-204; PASTOR, M., Viriato. El héroe hispano... Op. cit. pp. 145 ss.; SALINAS, M., «La Jefatura de Viriato y las sociedades del Occidente de la Península Ibérica», Palaeohispanica, 8, 2008, pp. 89-120.

${ }_{29}$ Apiano, Iber. 6, 11, 66. Apiano menciona el término Itukki, que puede identificarse bien con Tucci (Martos), o bien con Iptucci, Tejada la Vieja, Escacena del Campo (Huelva). 
mi opinión, en este contexto, la ciudad de Itucci (Tuccl) aparece localizada en el alto valle del Guadalquivir, próxima a las vías de penetración de la Meseta, por un lado, y la Bastetania, por otro.

La situación se hizo intolerable para Roma, pues la guerra se eternizaba y las sucesivas tropas romanas eran derrotadas sistemáticamente por Viriato. Esto preocupó profundamente al Senado y al pueblo romano que, en el 142-141 a.C., envió a la Ulterior a Quinto Fabio Máximo Serviliano, hermano de Emiliano, con el imperium proconsular. Llegó a Hispania con 18.000 soldados de infantería, 1.600 de caballería, 10 elefantes y 300 jinetes africanos. Un ejército demasiado escaso para enfrentarse a Viriato ${ }^{30}$.

Según Apiano, Serviliano comenzó liberando algunas ciudades del sur de Hispania, entre ellas, la localidad de Itucci, en la que estableció su base de operaciones y, posiblemente, su campamento. Desde allí se dirigió a la Beturia, es decir, a las tierras situadas entre el Guadalquivir y el Guadiana y saqueó cinco ciudades que se habían puesto de parte de Viriato. Después atacó a los conios del Sur de Portugal (pueblos no identificados, pero cuyo territorio se encontraba entre Algeciras y Lusitania), que también se habían alineado con Viriato y desde allí se dirigió hacia el Norte contra Viriato y sus lusitanos. Serviliano en este lugar se apodera de varias ciudades de las que Apiano menciona tres: Eskadia, Gemella y Obolkola:

\footnotetext{
«Entonces, por fin, Viriato, falto de provisiones y con el ejército mermado, prendió fuego a su campamento durante la noche y se retiró a Lusitania. Serviliano, como no pudo darle alcance, invadió la Beturia y saqueó cinco ciudades que se habían puesto de parte de Viriato. Con posterioridad, hizo una expedición militar contra los cuneos y, desde allí, se apresuró, una vez más, hacia los lusitanos contra Viriato. Mientras estaba de camino, Curio y Apuleyo, dos capitanes de ladrones, lo atacaron con diez mil hombres, provocaron una gran confusión y le arrebataron el botín. Curio cayó en la lucha, y Serviliano recobró su botín poco después y tomó las ciudades de Eskadia, Gemella y Obólcola, que contaban con guarniciones establecidas por Viriato, y saqueó otras e, incluso, perdonó a otras más. Habiendo capturado a diez mil prisioneros, les cortó la cabeza a quinientos, y vendió a los demás. Después de apresar a Cónnoba, un capitán de bandoleros que se le rindió, le perdonó sólo a él, pero le cortó las manos a todos sus hombres» ${ }^{31}$.
}

Parece claro que las dos ciudades que menciona Apiano: Ituci y Gemella hacen referencia a la ciudad de Tucci, más tarde colonia romana (Augusta Gemella Tucci), localizada en Martos (Jaén) ${ }^{32}$. Pero no todos los investigadores están de acuerdo con esta identificación. Así, algunos equiparan Itucci con Iptucci, posteriormente también colonia romana (Colonia Virtus Iulia Iptuci), identificable con Tejada la Vieja, en el término de Escacena del Campo (Huelva), situada en un em-

\footnotetext{
30 Cf. principalmente, PASTOR, M.: Viriato. El héroe hispano... Op. cit. pp. 169-173.

31 Apiano, Iber. 6, 11, 68.

32 Ut. Supra. Vid. nota 2.
} 
plazamiento estratégico entre la costa meridional y el Valle del Guadalquivir ${ }^{33}$. Realmente Iptuci se encuentra en una ubicación muy ventajosa para pasar a la Bastetania, por el valle del Guadajoz; además, la forma textual con la que la cita Apiano, Itucci, está más cercana a Iptucci que a Tucci.

Por otra parte, parece clara la diferencia entre Itucci y Gemella: los nombres son distintos y el papel que juegan en las campañas también. La primera aparece con una personalidad destacada, Apiano la cita tres veces, actuando como base romana, aunque en alguna ocasión es ocupada por Viriato, mientras que Gemella solo es citada una vez y entre las ciudades con guarnición lusitana que fueron tomadas por Serviliano, junto con Eiskadia, a la que R. Thouvenot, de manera muy forzada, identificó con Astigi (Écija, Sevilla) ${ }^{34}$, y con Obolkola, identificada con Obulco, la actual Porcuna (Jaén), localidad de gran valor estratégico y muy próxima a Martos (aproximadamente a 30 kilómetros), lo cual nos da pie para identificar, sin ninguna duda, a Tucci (Martos) con la Gemella citada por Apiano, pero admitiendo que éste comete un anacronismo, pues la denomina con el cognomen colonial que recibió un siglo más tarde con la fundación augústea.

Así, con la identificación de la Itucci/Gemella de Apiano podría quedar resuelto el problema de su identificación con Tucci=Martos, sin embargo, hay que hacer algunas consideraciones. En primer lugar, la dificultad de reconocer el grado de veracidad de los datos de Apiano $^{35}$, -incluidos estos topónimos-. Un autor que es capaz de confundir en varios pasajes de su obra a Sagunto con Cartago Nova, es inseguro a la hora de considerar la fidelidad de trascripción de topónimos y la identificación de los mismos. Además, en el desarrollo de la narración, cuando tratamos de concretar sobre un mapa las campañas militares, por ejemplo, es muy difícil hilvanar los acontecimientos de una manera completa y ordenada. Así, Apiano, al narrar las campañas de Viriato, que abarcan un espacio geográfico muy amplio (Lusitania, Bastetania, Turdetania, Carpetania) se pueden ver auténticos saltos de cientos de kilómetros, incluso de una línea a otra del texto. Por lo que es muy difícil identificar muchas de las ciudades que menciona.

Por su parte, otro autor que menciona la ciudad de Tucci es Diodoro Sículo al trasmitirnos una anécdota con la que Viriato se dirige a los habitantes de Tucci. Cuenta que un hombre que tenía dos mujeres, una joven y otra madura, acabó quedándose calvo por la insistencia de la joven en arrancarle los pelos canos y de la mayor en quitarle los negros; con ello pretendía advertir lo nefasto que podía ser para ellos una actitud indefinida entre los romanos y los lusitanos sin decantarse

${ }^{33}$ Cfr. CABALLOS, A., Contribución al estudio de la obra colonizadora de César en la Ulterior: CoIonia Claritas Iulia Vcubi, Iptuci Virtus Iulia y Asta Regia, Memoria de Licenciatura, Sevilla, 1978; Idem, «Iptuci, civitas stipendiaria del conventus Gaditanus», Gadees, 7, 1981, pp. 37 ss.; SALINAS, M., "La jefatura de Viriato...» Art. cit. p. 101.

34 THOUVENOT, R., Essai sur la province romaine de la Bétique, París, 1940, p. 128; de igual parecer era SCHULTEN, A., Fontes Hispaniae Antiquae. Las Guerras de 154-72 a. de J.C., Barcelona, 1937 , p. 119. En mi opinión, creo que es mejor considerarla como no localizada, y en todo caso, hay que buscarla en la provincia de Jaén y en algún lugar más próximo a Martos, Porcuna o Jaén.

${ }^{35}$ Cfr. CHIC, G., «Consideraciones sobre las invasiones lusitanas en Andalucía», Gades, V, 1980, p. 21. 
por ninguno, lo que le llevaría a perder todos sus ciudadanos. El propio autor lo expresa así:

«Era Viriato en sus razonamientos muy certero, como correspondía a su naturaleza no torcida ni educada por ningún maestro. Y así como los ciudadanos de Tucci no permaneciesen constantes en sus compromisos, sino que unas veces se declaraban por los romanos y, otras, por él, y esto lo hicieran en varias ocasiones, por medio de una fábula narrada con gracia, ridiculizó la inconstancia de su conducta al mismo tiempo que les advirtió de sus peligros. Explicó cómo un hombre de mediana edad tomó dos esposas, la más joven, para hacerle más semejante así misma, le arrancaba los cabellos canos, mientras que la más vieja le arrancaba los negros, hasta que en poco tiempo, depilado por ambas, se quedó calvo. El mismo destino esperaba a los habitantes de Tucci, pues como los romanos mataban a los enemigos de su partido, y los lusitanos suprimían a sus contrarios, pronto quedaría desierta la ciudad. Muchas otras cosas dicen que explicó así de un modo compendioso, siendo como era falto de instrucción regular, pero de una inteligencia formada por la práctica. Pues las palabras de un hombre que vive siguiendo la naturaleza son breves y sazonadas por la virtud y lo que se dice con palabras sencillas, breve y simplemente, es un apotegma para el que lo dice y para el que lo oye una sentencia memorable» ${ }^{36}$.

Independientemente de las interpretaciones de todo tipo que se han hecho de este texto, conviene llamar la atención de que Diodoro trasmite la forma que más se aproxima a nuestra Tucci y no a la Iptuci de Apiano. Y es lógico, puesto que Diodoro, cuya obra se publicó hacia el año 30 a.C. disponía de una mayor información o de fuentes más fidedignas que Apiano, cuya obra se publicaría ya muy avanzado el siglo II d. C.

Para completar esta identificación hay que hacer referencia también a un texto de Orosio en los que se refiere a estos mismos hechos y en el que cita una ciudad con el nombre de Buccia que, indudablemente debe identificarse con Tucci, como han señalado todos los investigadores. El texto de Orosio es el siguiente:

«Así el cónsul Fabio, luchando contra los lusitanos y Viriato, liberó la ciudad de Buccia que Viriato sitiaba, expulsando a los enemigos, y recibió su sumisión con otras muchas plazas fuertes. Cometió un crimen que sería execrable no ya para la fidelidad y moderación de los romanos, sino para los últimos bárbaros de Escitia, pues a quinientos principales de los pueblos cuya sumisión había recibido, invitados amistosamente, les cortó las manos ${ }^{37}$.

El análisis de los textos nos permite identificar la Tucci de Diodoro, con la Itucci de Apiano y la Buccia de Orosio y todas ellas con la posterior Colonia Augusta Gemella Tucci, que, como ya hemos señalado, se halla bien comunicada con la Meseta y con Bastetania. Por todo ello, se puede afirmar que la ciudad bética, citada indistintamente como Itucci/Tucci/Buccia, Gemella, cuadra perfectamente con la ciudad de Martos. En ella o en su ámbito se desarrollaron algunos aconte-

${ }^{36}$ Diodoro, Bibl. Hist. XXXIII, 7, 5.

37 Orosio, 5, 4, 12. 
cimientos de la guerra de Viriato y el propio Viriato debió vivir algún periodo de su vida en ella, aunque ignoramos en qué momento.

Pero sigamos con las guerras lusitanas y nuestro protagonista. Tras estos acontecimientos, el cónsul Serviliano avanzó hacia Lusitania persiguiendo a Viriato, pero fue sorprendido y derrotado por dos desertores romanos, Curio y Apuleyo. Ante esta inesperada circunstancia, el ejército de Serviliano tuvo que dar marcha atrás para defenderse de los asaltantes a los que derrotó y castigó severamente. Al año siguiente, Serviliano conquistó varias ciudades partidarias del lusitano, impidiéndole con ello su aprovisionamiento. Parecía que el fin de Viriato estaba cerca cuando Serviliano consiguió acorralarle junto a la ciudad de Erisana (tal vez, Azuaga, o Zalamea, en Badajoz), pero, una vez más, una estratagema hizo cambiar la situación y las tropas romanas quedaron atrapadas en el desfiladero. Viriato alcanzó un gran éxito sobre las tropas romanas, que huyeron despavoridas. Poco después, acorraló al grueso del ejército consular en un lugar del que no podría escapar, de manera que la derrota definitiva del ejército romano parecía inevitable. Se preveía el mayor triunfo de Viriato sobre los romanos. No había esperanza para ellos; sin embargo, cuando todo estaba a su favor, Viriato entabló negociaciones con Serviliano que condujeron a la conclusión de un tratado de paz. El ejército romano se retiró y Viriato confirmó todo el territorio que poseía como independiente. A partir de ese momento, los lusitanos -hecho insólito- serían considerados como amigos del pueblo romano. Serviliano aceptó todas las condiciones impuestas por Viriato. En adelante, romanos y lusitanos respetarían los límites y fronteras de ambos pueblos, que se establecieron en los que ocupaban en ese momento. Pero lo más sorprendente es que el tratado fue ratificado por el Senado que otorgó a Viriato el título de amicus populi romani («amigo del pueblo romano»), reconociéndole incluso como rey, aunque dio la consigna a sus gobernadores de que debían deshacerse de él como fuera, puesto que sus victorias no sólo humillaban a Roma, sino que ponían en sus manos los ricos territorios de la Bética ${ }^{38}$.

Por dicho tratado, como afirma Apiano, los romanos reconocían la soberanía de Viriato sobre las tierras que poseía en ese momento y los hombres que estaban con él. Ahora bien, es difícil saber cuales eran exactamente los territorios sobre los que el tratado reconocía el dominio de Viriato. Por la mención de los oppida de Arsa, Itucci/lptucci, Urso y Tucci podemos suponer que dicho dominio se extendía sobre la Beturia y algunas ciudades del Valle del Guadalquivir, donde otras ciudades como Corduba, Italica, Carteia o Gades permanecían firmemente en manos de los romanos. Es probable que dicho dominio se extendiera también por el Algarbe portugués y hasta el curso del Tajo, pero no debió extenderse más allá de las estribaciones del Sistema Central.

Pero la paz duró muy poco tiempo. Aunque el Senado y el pueblo romano habían ratificado, ciertamente, el tratado, no faltaron voces que se alzaron en su contra, declarando dicha paz como indigna al haber cedido a Viriato territorios roma-

38 Ibidem, pp. 173-180. 
nos. La paz también fue considerada por algunos como «vergonzosa». Por ello, cuando, en el 139 a. C., Quinto Servilio Cepión llegó a Hispania en calidad de procónsul, la situación va a cambiar de manera radical. Su actitud fue nuevamente guerrera. Primero solicitó autorización del Senado para promover algunas acciones contra Viriato, luego se manifestó en contra del tratado, presentándolo ante el Senado como contrario al honor de Roma y, finalmente, inició las hostilidades. Viriato se acogió al tratado, pero el Senado anuló el tratado de paz y dio a Cepión la posibilidad de retomar abiertamente la guerra. Viriato se vio obligado a evacuar algunas ciudades de la Beturia, como Arsa/Erisana, y se retiró hacia la Carpetania hasta donde lo siguió Cepión. Cuando Cepión lo tenía cercado, Viriato empleando nuevamente su exitosa táctica militar consiguió escaparse, pero Cepión lo persiguió por las montañas lusitanas hasta los territorios de los vetones y galaicos. Este camino sería después conocido como «Vía de la Plata»39.

Viriato podría haber resistido aún durante algún tiempo en las montañas lusitanas, pero los lusitanos estaban cansados de guerra y exigían la paz. Por eso de nuevo se iniciaron negociaciones entre Viriato y el cónsul romano, Popilius Lenas. Los romanos exigieron la entrega de todos los desertores y de los rebeldes más destacados, a los que cortaron las manos, y la entrega de las armas, lo que suponía la mayor afrenta que se le podía hacer al pueblo lusitano. Tales exigencias hicieron que Viriato rompiera las negociaciones y se retirara nuevamente a sus montañas. Aunque pronto se retomaron nuevamente, aunque ahora, no con el cónsul, sino con Cepión. Viriato envió al campamento de Cepión, a tres de sus lugartenientes, a los que consideraba sus fieles amigos, Audax, Ditalcos y Minuros (o Nicorontes) ${ }^{40}$, naturales de Urso (Osuna). No fue difícil para Cepión hacerles renegar y convencerles para asesinar a Viriato, prometiéndoles ventajas personales y ofreciéndoles ricos presentes y tierras para vivir en paz. Los enviados volvieron al campamento de Viriato y lo asesinaron mientras dormía tranquilamente en su tienda. Según cuenta la tradición, Viriato apenas dormía y siempre se acostaba con su armadura, por lo que le apuñalaron en el cuello, el único lugar vital que no estaba protegido. Luego huyeron de nuevo al campamento romano en busca de la recompensa, pero se equivocaron en sus cálculos. Viriato encontró la muerte por la traición e infidelidad de sus propios compatriotas y no por el valor de Cepión ${ }^{41}$.

En Roma su asesinato fue considerado como una acción indigna. Los asesinos no recibieron la paga prometida por Cepión. El Senado negó la confirmación del pacto y el triunfo a Cepión. La célebre frase «Roma no paga traidores» no es más que una invención posterior, pero recoge perfectamente el sentir de la versión tradicional, que sostiene que los romanos nunca habían aprobado que un jefe muriese a manos de sus propios soldados. Seguramente, la frase es de una época

39 Ibidem, pp. 181-184. Para la «Vía de la Plata», cfr. principalmente, AA.VV., La Ruta de la Plata de Sevilla a Gijón, Ediciones Lancia, León, 1993; vid. también, ROLDÁN, J. M., Iter ab Emerita Asturicam. El camino de la plata, Salamanca, 1971.

40 El nombre Nicorontes lo da Diodoro (XXXIII, 31), mientras que el de Minurus se puede ver en Apiano (Iber. 71) y también en el papiro de Oxyrrinco (Oxyrh, 197).

41 Cfr. principalmente, PASTOR, M., Viriato. El héroe hispano... Op. cit. pp. 184-189. 
posterior a los hechos ocurridos y se dijo para tratar de ocultar la vergüenza que producía a los romanos ser responsables de acciones semejantes.

La muerte de Viriato la narran Diodoro y Apiano. Diodoro nos dice:

"Audax, Ditalco y Nicorontes, de la ciudad de Urso, amigos y emparentados entre sí, dándose cuenta de que la supremacía de Viriato empezaba a ser puesta en peligro por los romanos y temiendo por ellos mismos, decidieron ganarse la benevolencia de los romanos con algún servicio; de esta manera, pretendían ganarse para ellos su propia seguridad. Viendo que Viriato deseaba poner fin a la guerra, se ofrecieron para persuadir a Cepión a hacer un tratado de paz si se les enviaba a ellos como emisarios. Asintió con gusto el caudillo y poco después se presentaron ante Cepión y le persuadieron sin dificultad a garantizarles su seguridad personal si le anunciaban el asesinato de Viriato. Después de dar y recibir garantías mutuas sobre lo pactado, regresaron a toda prisa al campamento. Dijeron que habían convencido a los romanos respecto a la paz e hicieron nacer grandes esperanzas en Viriato, animándole en lo que de sus proyectos más se alejaba de la realidad. Pero estos, se aprovecharon de la confianza y de la amistad que Viriato les tenía, entraron a escondidas y por la noche en su tienda de campaña y con sus espadas le mataron de un certero golpe. Luego salieron inmediatamente del campamento y a través de unos atajos por el monte, llegaron sin problemas ante Cepión a reclamar su recompensa.

El cadáver de Viriato fue honrado magníficamente y con espléndidos funerales. Hicieron combatir ante su túmulo doscientas parejas de gladiadores, honrando así su extraordinario valor. En efecto, Viriato fue de una gran combatividad en los peligros, muy sagaz en prever lo que convenía y, lo que es más, pasó todo el tiempo de su jefatura siendo muy querido por sus soldados, más que nadie. En el reparto del botín no tomaba nunca una parte mejor que los otros y de lo que tomaba, lo obsequiaba a los soldados que más se lo merecían o a los que más lo necesitaban. Era también muy sobrio. No dormía mucho y no retrocedía ante ningún peligro, ni nada le apetecía en exceso. Las pruebas de su valor son evidentes, pues durante lo doce años que estuvo al frente de los lusitanos no hubo ninguna indisciplina en sus soldados. Tras su muerte, se deshizo el ejército lusitano al quedar privado de semejante jefe ${ }^{42}$.

Apiano cuenta prácticamente lo mismo, aunque omite el hecho de que fueran oriundos de Urso y cambia el nombre de Minuros por el de Nicorontes:

«Viriato envió a sus más fieles amigos Audax, Ditalcón y Minuro a que negociasen la paz con Cepión; Cepión los corrompió con magníficos dones y promesas, y los indujo a prometerle la muerte de Viriato. Y lo cumplieron del modo siguiente: Viriato dormía poco por sus cuidados y fatigas; y aún las más veces dormía con las armas, para estar dispuesto a todo al momento de despertarse. Así, aún de noche era posible a sus amigos acercarse a él. Valiéndose de esta costumbre, Audax y sus cómplices, estando Viriato en su primer sueño, entraron en la tienda como si llevaran prisa y le asesinaron hiriéndole en el cuello, único lugar del cuerpo que ofrecía al descubierto. Sin que nadie se diese cuenta de lo sucedido, por lo certero del golpe, huyeron al campamento de Cepión y reclamaron su recompensa. Ce-

42 Diodoro, Biblioth. Hist. XXXIII, 21. 
piòn les permitiò que conservasen los que ya les había dado, pero en cuanto a lo que pedían, los remitió a Roma. Al rayar el alba, los sirvientes de Viriato y todo el ejército, convencidos de que dormía, se extrañaban de que durmiese más tiempo del que acostumbraba, hasta que algunos se dieron cuenta de que yacía muerto y con sus armas. Al instante se alzó por todo el campamento un gran lamento y griterío; todos lloraban su muerte y se lamentaban de su propio mal, considerando qué peligros les amenazaban y qué gran caudillo perdían. Lo que más le pesaba era no poder encontrar a los asesinos. El cadáver de Viriato, magníficamente vestido, fue quemado en una altísima pira. Se inmolaron muchas víctimas, mientras que los soldados, tanto los de infantería como los de caballería, corrían en formación alrededor de la pira, con sus armas y entonando sus glorias al modo bárbaro. No se retiraron de allí hasta que el fuego de la hoguera se extinguió completamente. Terminado el funeral, celebraron combates singulares sobre su túmulo» ${ }^{43}$.

Los hechos que narran ambos textos hay que situarlos en el 139 a. C., cuando Q. Servilio Cepión, que actuaba en este momento como procónsul, continúa la labor de su predecesor Q. Fabio Máximo Serviliano en su ofensiva romana para recuperar los valles del Guadalquivir y del Genil con la finalidad de perseguir y acabar con Viriato en la Beturia, donde éste, aprovechando una victoria en la localidad de $\mathrm{Arsa}^{44}$, había solicitado la paz desde una posición de fuerza. Cepión denuncia ahora el tratado de paz que había llegado a firmarse y persigue a Viriato hacia el norte, entre carpetanos y vetones. El cónsul Popilius Lenas se une a la ofensiva de Cepión y Viriato vuelve a pedir la paz.

En ambos textos se describen también los funerales de Viriato al que sus compañeros consideraban como un héroe. La mayor parte de los historiadores greco-latinos ven a Cepión el verdadero instigador del complot que causó la traición y posterior asesinato de Viriato. Viriato era considerado como un héroe por sus propios compañeros; de aquí que participen en la revivificación del caudillo derramando su propia sangre sobre su tumba en un torneo fúnebre, similar a los juegos que Aquiles celebró en honor de su amigo Patroclo y que fueron introducidos por los romanos en el 264 a. C. desde el Sur de Italia ${ }^{45}$.

Cuando se descubrió el asesinato de Viriato, el sentimiento del pueblo lusitano fue extraordinario. Los lusitanos le hicieron unas exequias singulares, casi divinas. El cadáver fue quemado sobre una pira gigantesca y ofrecieron a los dioses innumerables víctimas. Todo el ejército estuvo presente en el entierro entonando cánticos de alabanza a su general y bailando alrededor del fuego. Una vez extinguido el fuego, se levantó un gigantesco túmulo y todos se sentaron a su alrededor

43 Apiano, Iber. 6, 11, 62.

44 Sobre su localización, cfr. GARCÍA Y BELLIDO, Mª. P., «Sobre las dos supuestas ciudades de la Bética llamadas Arsa. Testimonios púnicos en la Baeturia Túrdula», Anas, 4, 1993, pp. 81-92.

45 Una supervivencia de estos juegos serían, más tarde, las luchas de gladiadores en los anfiteatros romanos. cfr. principalmente, VILLE, G., La gladiature en Occident des origenes à la mort de Domitien, Roma, 1981; vid. también, BRICEÑO, S. I., Los gladiadores de Roma. Estudio histórico, legal y social, Bogotá, 1986; PASTOR, M., «Munera gladiatorium: Aspectos sociales», en S. Crespo Ortíz de Zárate y A. Alonso Ávila (Ed.), Scripta Antiqua in honorem Ángel Montenegro Duque et José María Blázquez Martínez, Valladolid, 2002, pp. 485-499; MEIJER, F., Un giorno al Colosseo. Il mondo dei gladiatori, Roma-Bari, 2006; KYLE, D. G., Sport and Spectacle in the Ancient World, Oxford, 2007. 
guardando un profundo silencio. Luego, ante sus cenizas, más de doscientas parejas de gladiadores combatieron en su honor.

El hecho de que en el entorno de Viriato se encontrasen personas del valle del Genil, concretamente de Osuna, es de un gran interés, puesto que podemos ver a Viriato como aglutinador de una serie de virtudes guerreras que habrían de despertar la admiración y el deseo de seguirle a grandes masas de población. Esto se aprecia claramente cuando se describen los funerales del héroe. A un héroe o jefe al que se considera lleno de una virtus que es necesario exaltar y mantener viva. De ahí que, si el culto a los muertos se considera una de las manifestaciones más antiguas del sentimiento religioso, el culto al héroe muerto destaca de una manera especial. Hay que tener presente que una sociedad siempre se ha entendido como enraizada en el tiempo, o sea que se ha considerado integrada siempre tanto por las personas vivas como por aquellas que les han precedido en este mundo y que ahora forman parte de ese elemento fundamental para cualquier pueblo que es su Historia. Al comienzo, a los muertos parece habérseles vivificado con la sangre derramada en auténticos sacrificios humanos. Unos sacrificios humanos que perduraron en Roma hasta el 97 a.C., año en que fueron prohibidos ${ }^{46}$.

En este sentido, no debe extrañarnos que Estrabón escriba:

«los lusitanos son dados a los sacrificios y examinan las entrañas sin separarlas del cuerpo; se fijan además en las venas del costado y adivinan palpando. Hacen también predicciones por las entrañas de sus cautivos de guerra, a los que cubren con sayos. Luego, cuando son heridos por el arúspice en las entrañas, adivinan en primer lugar por la forma en que caen. Cortan las manos de los prisioneros y consagran las diestras ${ }^{47}$.

Esta práctica nos lleva directamente al mundo del honor buscado por el guerrero, que se sustantiva en despojar al enemigo de una parte importante de su cuerpo, como también hacían los romanos, egipcios y otros pueblos ${ }^{48}$. El honor obtenido en todos los casos se consideraba muy grande. $Y$ el honor es el elemento más sustancial en la vida de un guerrero. Una vida que termina en buena medida con la muerte y que sólo el sacrificio sangriento podía paliar de algún modo, pues

${ }^{46}$ Cfr. CLAVEL-LÉVÊQUE, M., «Rituels de mort et consommation de gladiateurs: images de domination et practiques imperialistes de reproduction», Hommages a Lucien Lerat, pp. 189-191.

47 Estrabón, III, 3, 6; cfr. el comentario de J. Millán León a este texto en la traducción de MEANA, $\mathrm{M}^{\mathrm{a}}$ J. y PIÑERO, F., op. cit., p. 84. Dice este autor: «esta forma de vaticinio se atestigua también entre los galos, aunque no hubo aquí una organización sacerdotal como la de los druidas: las funciones religiosas eran compartidas por los adivinos y los jefes de unidades gentilicias». Vid. al respecto, GARCíA QUINTELA, M. V., «El sacrificio humano adivinatorio céltico y la religión de los lusitanos», Polis, 3, 1991, pp. 25-37.

${ }_{48}$ De mismo modo, como dice Apiano, durante las guerras contra Viriato, Q. Fabio Máximo Serviliano, tras capturar a un cierto Connobas, lo dejó en libertad, pero a sus hombres les cortó las manos (Apiano (Iber. 68), Lo mismo cuentan Valerio Máximo (2, 7, 11), Frontino, 4, 1, 42 y Orosio (5, 4, 12). Igual ocurrió en Egipto tras la expulsión de los hicsos; cfr. PRITCHARD, J. B., La sabiduría del antiguo oriente, Barcelona, 1966, p. 204; y en Esparta, con los espartanos del siglo VII-VI a.C., como informa el lírico Tirteo (10, 25); cfr. BETHE, E., «Die dorische Knabenliebe. Ihre Ethik und inre Idee», Rheinische Museum, 62, 1907, pp. 464-465. 
la sangre caliente vivificaba al alma del difunto y le permitía participar en el recuerdo de los vivos. De ahí que los compañeros del guerrero, en este caso de Viriato, quieran participar en la revivificación del caudillo llorado derramando su propia sangre sobre la tumba en un torneo fúnebre ${ }^{49}$. De hecho, existen fuertes indicios para creer que, en sus orígenes, los juegos olímpicos no eran otra cosa sino una asamblea o reunión para celebrar juegos fúnebres.

¿Ocurría lo mismo en el sur de la Península Ibérica? No lo sabemos con seguridad, pero es muy posible. Un testimonio de ello puede encontrarse en las llamadas estelas decoradas del suroeste, que se encuentran entre el valle del Zêzere, al Norte del Tajo, y los del Guadajoz y del Genil ${ }^{50}$, es decir, en el área que actuaban las tropas de Viriato ${ }^{51}$. En ellas suele representarse a un guerrero, con sus armas y atributos guerreros (espejo y carro), representados de manera esquemática mediante la yuxtaposición de los elementos que lo componen. En una de ellas, procedente de Ategua (Córdoba), se nos muestra el cadáver sobre una pira y una figura con las manos en la cabeza en señal de lamentación; y en la parte inferior, aparecen los animales que estarían destinados al sacrificio (tal vez, caballos o toros), y luego, bajo una escena en la que el personaje se dispone a subirse en el carro de parada, dos grupos de cuatro y tres personajes, que se han interpretado como individuos que ejecutan la danza fúnebre ${ }^{52}$. Todos estos elementos, como ya vimos, aparecen en la descripción que hacen Diodoro de Sicilia y Apiano de los funerales de Viriato» ${ }^{53}$.

Por otro lado, si entre los lugartenientes y hombres de confianza de Viriato se mencionan a tres ursonenses, es fácil deducir que compartirían el mismo tipo de vida, es decir, el militar. El guerrero es un individuo que voluntariamente busca en la lucha su forma de vida. Y esto es, precisamente lo que decía Dión Casio de Viriato: «no emprendía la guerra ni por avaricia, ni por amor al mando, ni por cólera, sino que la hacía por ella misma»54. Lo único que pretende es conseguir prestigio y estima, que se mide por el honor que otros rinden al guerrero por su sabiduría y valor, y que se materializa en la parte especial del botín que le corresponde si ha logrado que otros le sigan en sus empresas. El valor en el combate era fundamental, pero debía ir acompañado por la capacidad oratoria de convencer a los demás y la generosidad para con sus compañeros, primero, y para con el conjunto de su pueblo después. Características, todas ellas, que los textos resaltan en la figura de Viriato y que -hemos de suponer que compartían sus iguales- como esos

49 Todo esto nos recuerda también la épica homérica, que narra los juegos que Aquiles celebró en honor de Patroclo; cfr. Homero, Ilíada, XXIII, vv. 798 ss.

50 Cfr. GALÁN DOMINGO, E., Estelas, paisaje y territorio en el Bronce Final del Suroeste de la Península Ibérica, Madrid, 1993; CHIC, G., «Las estelas del Suroeste hispano y el arreglo corporal del guerrero", V Coloquio sobre lenguas y culturas paleohispánicas, Colonia, 25-29 de Septiembre de 1989. Actas, Salamanca, 1993, pp. 273-279.

51 Ut supra, vid. las notas 12 y 21; principalmente, PASTOR, M.: Viriato. El héroe hispano... Op. cit., pp. 153 ss.

52 Cfr. principalmente, BENDALA, M.: «Notas sobre las estelas decoradas del Suroeste y los orígenes de Tartessos», Habis, 8, 1977, pp. 191-193.

53 Ut supra, vid. las notas 42 y 43.

54 Dión Casio, Hist. XXII, 77-78. 
tres ursonenses (Audax, Ditalcos y Minuros/Nicorontes) de mediados del siglo II a. C. que, finalmente acabaron con Viriato mediante la traición.

Los guerreros son un elemento de individualización en una sociedad gentilicia: forman grupos en los que rige el principio de igualdad y en los que la palabra de uno se contrapone a la de otro en una dialéctica que difícilmente podríamos encontrar en el marco de las familias patriarcales o en los clanes a los que, cada uno por su lado, también pertenecían. Su sistema de relación no está en la consanguineidad, sino en el control del territorio, donde la línea de preferencia se marca simplemente por el prestigio que alguien puede llegar a alcanzar y, en consecuencia, hacen que sus seguidores o clientelas puedan ser importantes ${ }^{55}$. Los jefes de los clanes buscarán el apoyo de estos guerreros, cuyo poder es distinto, y no dudarán en entregar a sus hijas en matrimonio para estrechar lazos con ellos, como sabemos que hizo Viriato al emparentarse con el rico Astolpas tras celebrar los rituales religiosos que acompañaban a la boda ${ }^{56}$. Son ellos quienes se establecen en lugares fortificados, como son los casos de Urso y Tucci, los que en torno a sí configuran una vida política.

En este sentido, los núcleos permanentes de población o ciudades (oppida, urbes) se van configurando en torno a un ejército, con sus normas y religión. Y, probablemente esto es lo que ocurrió con Urso y Tucci que, ya en tiempos de Viriato, eran auténticas ciudades fortificadas (oppida). La evolución propia del sistema político iría desarrollando las jefaturas estables y los grupos de guerreros se irían transformando en masas de combatientes que siguen a su jefe ${ }^{57}$. De hecho, posiblemente en parte por la necesidad de enfrentarse a Cartago, primero, y a Roma, después, los grupos de guerreros se irían transformando en aristocracias consolidadas establecidas a la cabeza de organismos jerárquicos. No obstante, el espíritu del guerrero tardaría mucho en desaparecer, y es difícil pensar que la pérdida del honor que podía suponer la traición al jefe no dejase de causar vergüenza, como muestran las fuentes romanas que hablan del asesinato de Viriato ${ }^{58}$.

Las jefaturas habitaban en los oppida, y la inmensa mayoría de la población vivía diseminada por el campo. Estas jefaturas eran apoyadas por la aristocracia romana, que veía en ellas un medio cómodo de control del territorio provincial. Por esta razón, durante las guerras contra Viriato se había constituido en el Sur y Oeste de Hispania un poder político virtualmente independiente de Roma, que asumió la forma de una monarquía, similar a las monarquías helenísticas. Su núcleo principal estaba en la Baeturia céltica y túrdula, entre el Guadiana y el Guadalquivir,

55 Sobre estos aspectos, cfr. principalmente, CHIC, G., «Urbs, polis, civitas», Los orígenes de la ciudad en el Noroeste hispánico, Lugo, 1999, pp. 145-170; IDEM, «Una visión de Urso a través de las fuentes literarias antiguas», art. cit. pp. 188-213.

56 Cfr. principalmente, PASTOR, M., Viriato. El héroe hispano... Op. cit. pp. 49-57, donde pueden leerse los textos de Diodoro que narran el episodio de las bodas de Viriato; vid., también, la nota 12.

57 Cfr. principalmente, CHIC, G., «La transformación de los sistemas de convivencia: hacia la formación de las urbes en el sur de Hispania», Gades, 22, 1998, pp. 221-239; también, RUíZ, A., «Origen y desarrollo de la aristocracia en época ibérica, en el alto Valle del Guadalquivir», Les princes de la protohistoire et l'emergence de l'État, Nápoles-Roma, 1999, pp. 97-106.

${ }^{58}$ Cfr. principalmente, PASTOR, M.: Viriato. El héroe hispano... Op. cit. pp. 185-180. 
donde ya existían verdaderas ciudades con una organización social y política muy compleja, heredera de las civilizaciones anteriores.

El territorio y los pueblos sobre los que gobernaba Viriato no eran solo grupos tribales, más o menos civilizados, sino ciudades de la Hispania meridional, con una organización social y política compleja y siglos de civilización a sus espaldas. Las fuentes mencionan algunas de ellas: Tribola, Urso, Gades, Baicor, Itucci, Iscandia, Gemella, Obulcola, Erisane, Buccia, Tucci, Erisane/Arsa. Los jefes militares habitaban en los oppida, y la inmensa mayoría de la población vivía diseminada por el campo. Estas jefaturas eran apoyadas por la aristocracia romana, que veía en ellas un medio cómodo de control del territorio provincial.

En algunas de estas ciudades, como Urso y Tucci existían partidarios de los romanos y partidarios de Viriato. Entre estos últimos había aristócratas locales y/o destacados guerreros de Viriato que, a su vez, poseían grandes propiedades de tierra y de ganado. A este grupo pertenecerían, sin duda alguna, sus propios asesinos (Audax, Ditalcos y Minuros o Nicorontes), que no veían con buenos ojos el prestigio y el poder que había alcanzado Viriato, de aquí que se consideraran traicionados por su jefe y se conjuraran contra él ${ }^{59}$.

La consolidación del poder de Viriato se produjo cuando el Senado de Roma le nombró amicus populi romani y reconoció su poder sobre todas las tierras que poseía en Lusitania. Con este acto que, para los romanos, tenía una significación política precisa, Roma situaba a Viriato, jefe de los lusitanos, al mismo nivel que a otros destacados reyes aliados, como Hierón II de Siracusa, Micipsa, Masinisa o los Atálidas de Pergamo. De esta manera, la propia sociedad lusitana había evolucionado hacia formas políticas más complejas que, en un momento determinado, asumieron la forma de una posible monarquía, representada por el propio Viriato.

La muerte de Viriato significó, prácticamente, el comienzo del final de la resistencia de los lusitanos a la expansión romana en la Hispania Ulterior. Su sucesor, un tal Táutalos carecía de las cualidades de Viriato y pronto fue derrotado por Cepión que le obligó a capitular sin condiciones, aunque los prisioneros fueron tratados con benevolencia y no se les cortaron las manos, como antes había hecho Galba e incluso se les repartieron tierras para que no se dedicaran a saquear las de sus vecinos.

Así terminaron las guerras que enfrentaron a Roma contra Viriato, en las que las ciudades de Osuna (Urso) y Martos (Tucci) jugaron un rol importante, puesto que en ellas o en sus alrededores se desarrollaron muchos de los acontecimientos que determinaron el final de las guerras, como el propio asesinato de Viriato.

59 En este contexto cabe preguntarnos por los motivos que llevaron a estos guerreros ursonenses a traicionar a su jefe. No lo sabemos con seguridad, pero siempre hemos pensado que actuaron, no por avaricia (eran ricos propietarios de tierras en la fértil Osuna), ni por deseos de sustituir a su jefe (ocupaban una posición de privilegio en el ejército de Viriato), sino porque consideraron que el propio Viriato les había traicionado a ellos por haber aceptado una paz con los romanos de la que solo él sería el gran beneficiado y no el resto de los guerreros y conciudadanos. Cfr. al respecto, PASTOR, M., Viriato. El héroe hispano... Op. cit. pp. 233-257. 


\section{RELACIÓN DE FIGURAS}

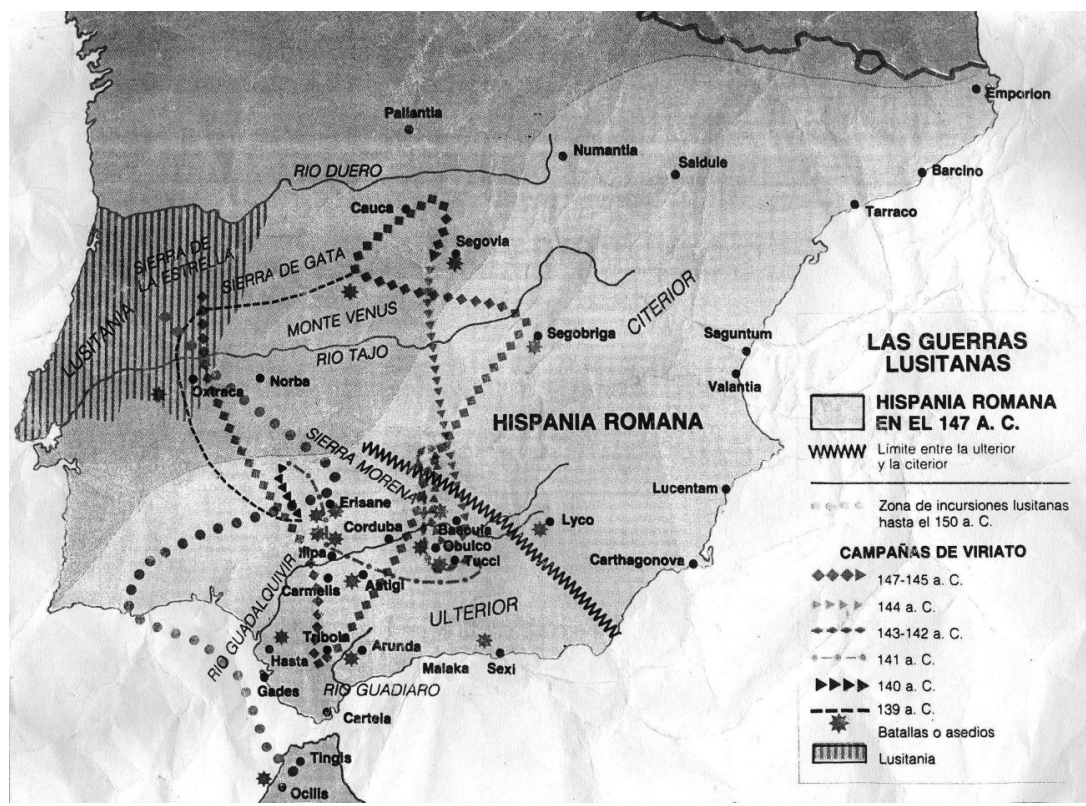

Fig. 1. Las guerras lusitanas y las campañas de Viriato.

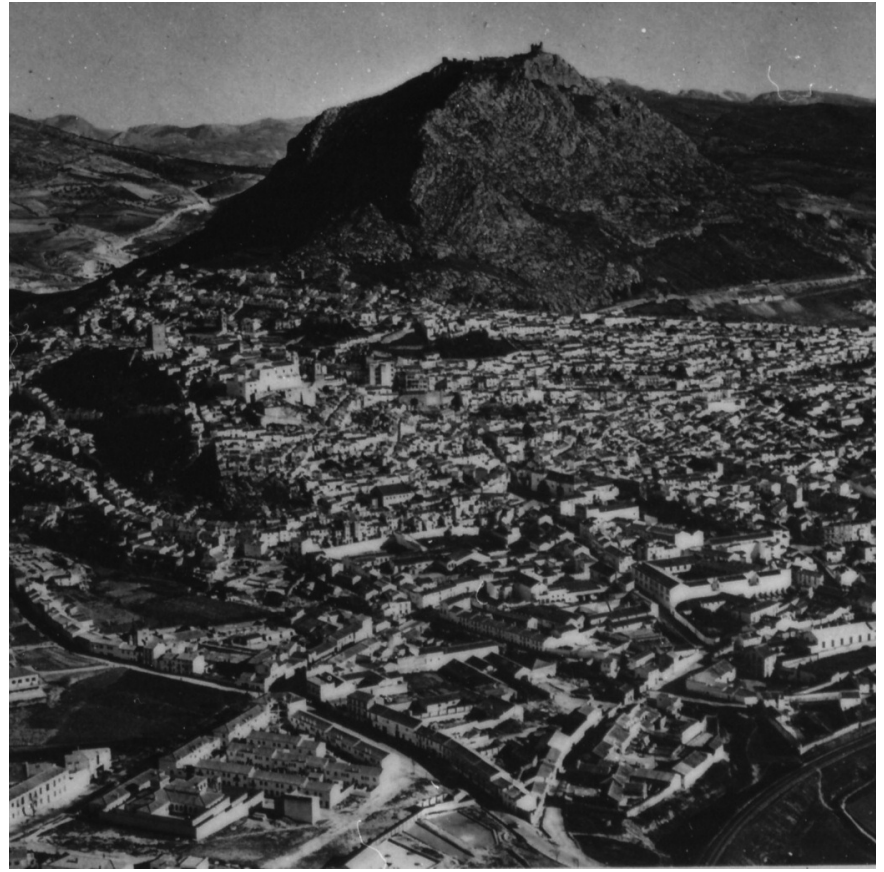

Fig. 2. Vista aérea

de Martos (antigua Tucci), 
Fig. 3. Viriato y otros héroes de la España Antigua.
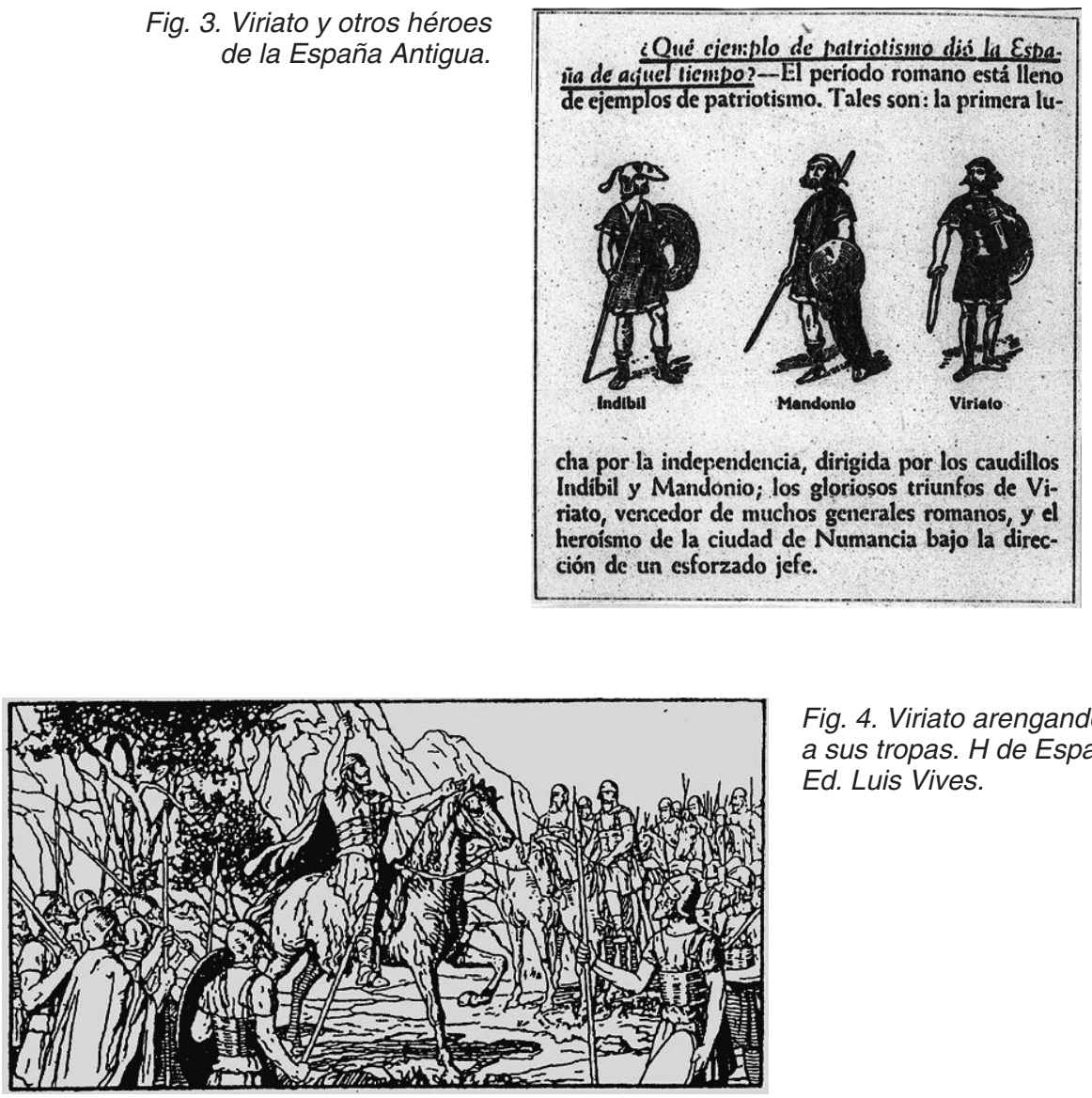

Fig. 4. Viriato arengando a sus tropas. H de España, Ed. Luis Vives.

Fig. 5. Guerrero ibérico con escudo (Osuna, Sevilla).

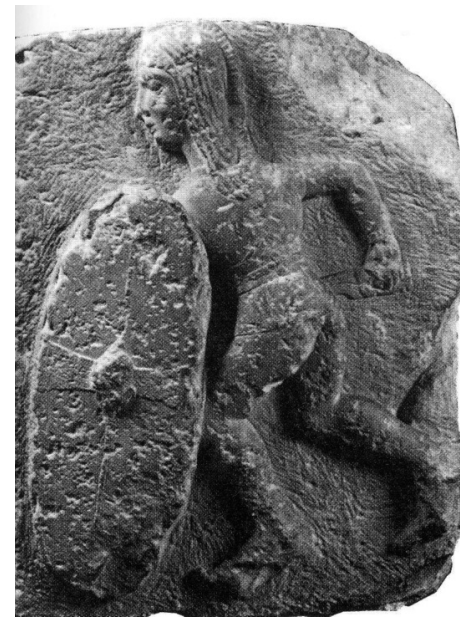


Viriato y las ciudades de La Bética

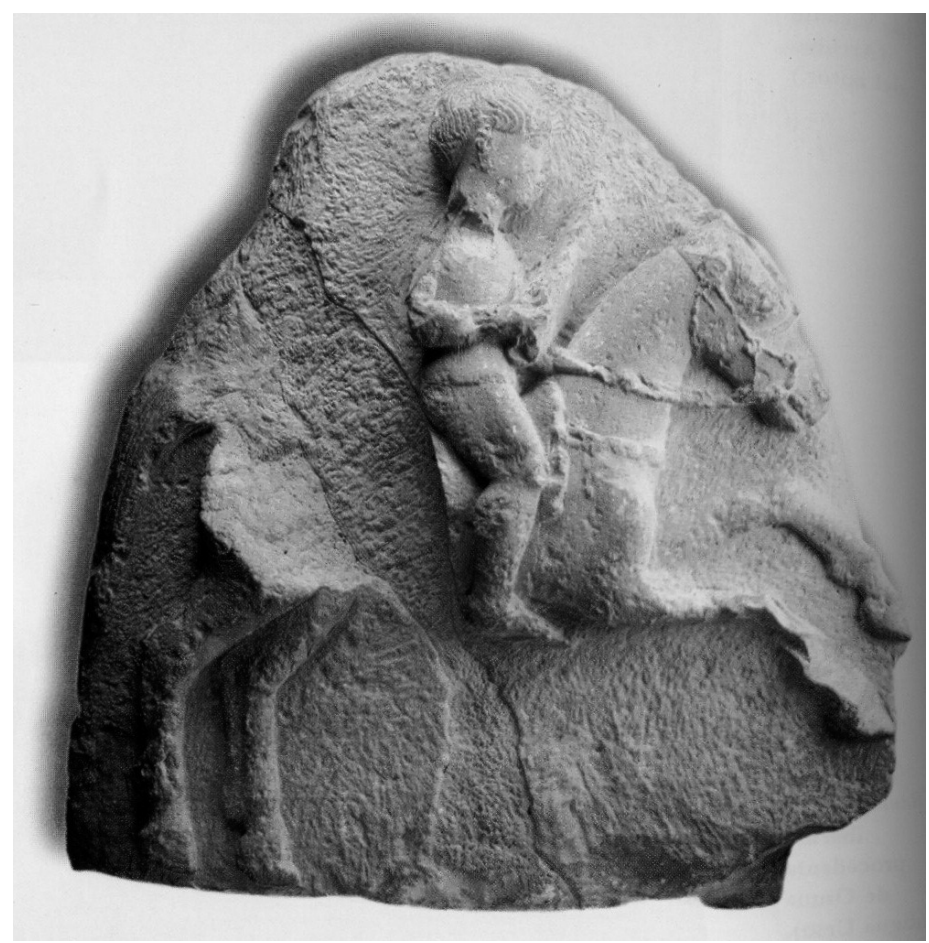

Fig. 6. Estela ibérica con figura de jinete (Osuna, Sevilla).

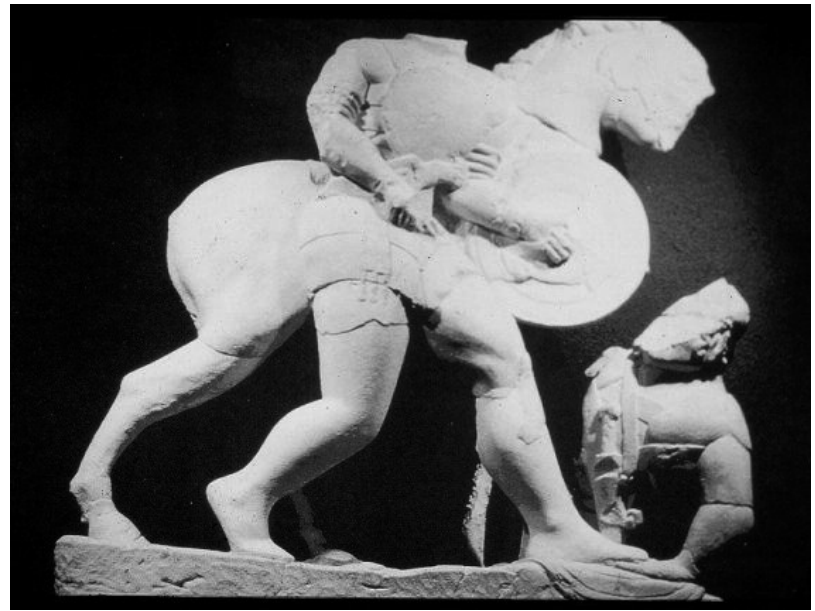

Fig. 7. Grupo de jinete (Porcuna, Jaén). 


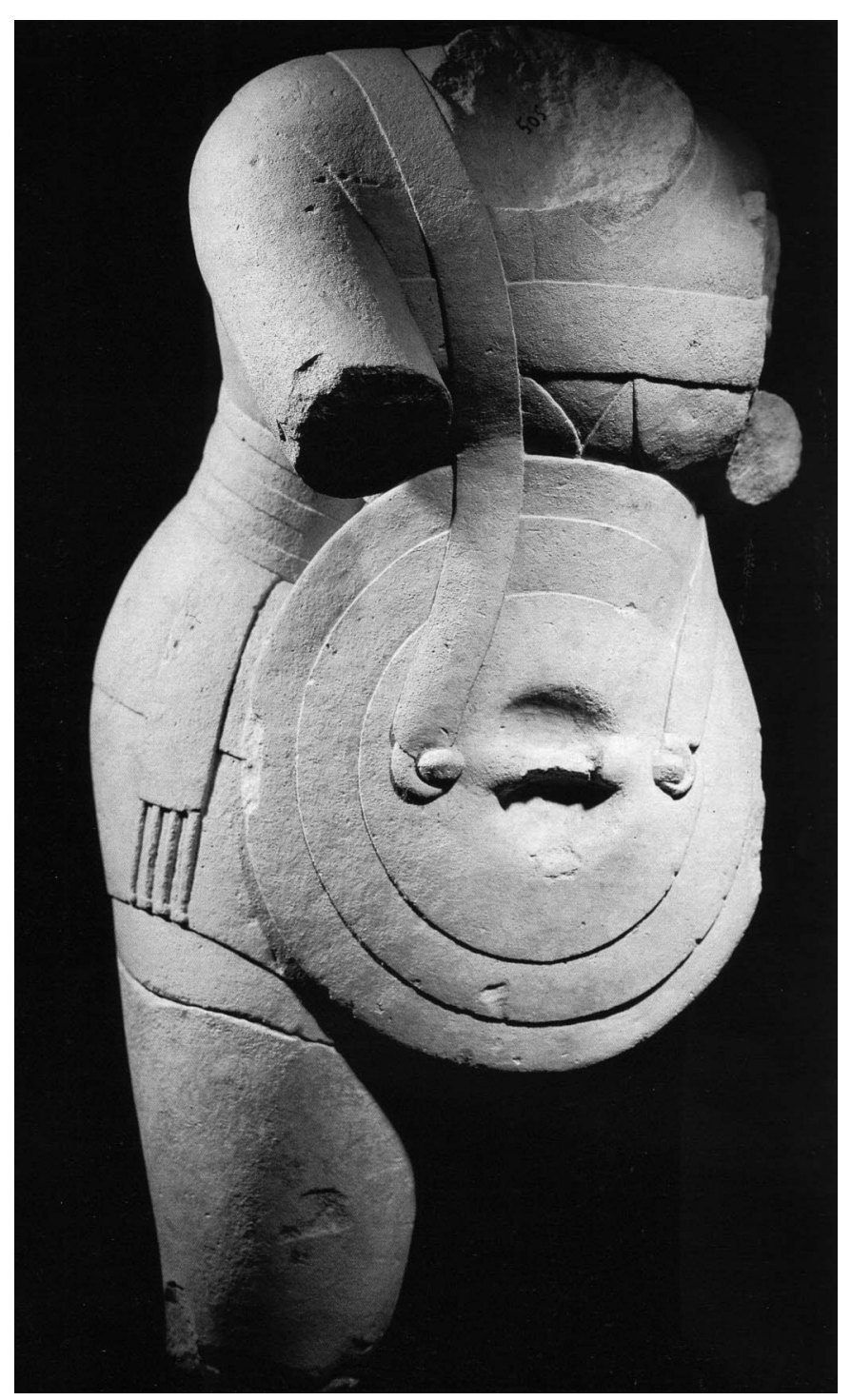

Fig. 8. Guerrero ibérico (Cerrillo Blanco, Porcuna (Jaén). 
Viriato y las ciudades de La Bética

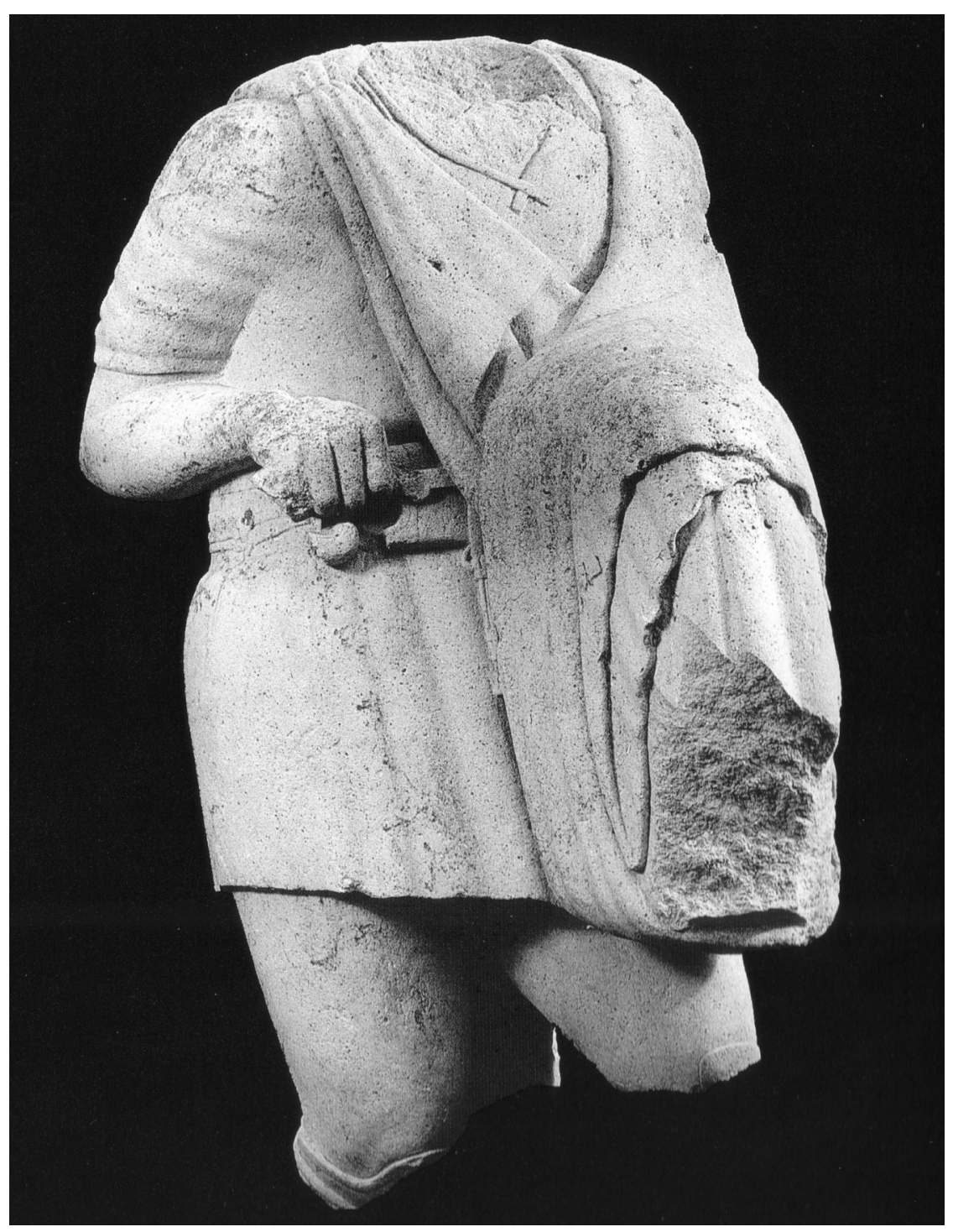

Fig. 9. Guerrero ibérico (El Pajarillo, Huelma (Jaén). 


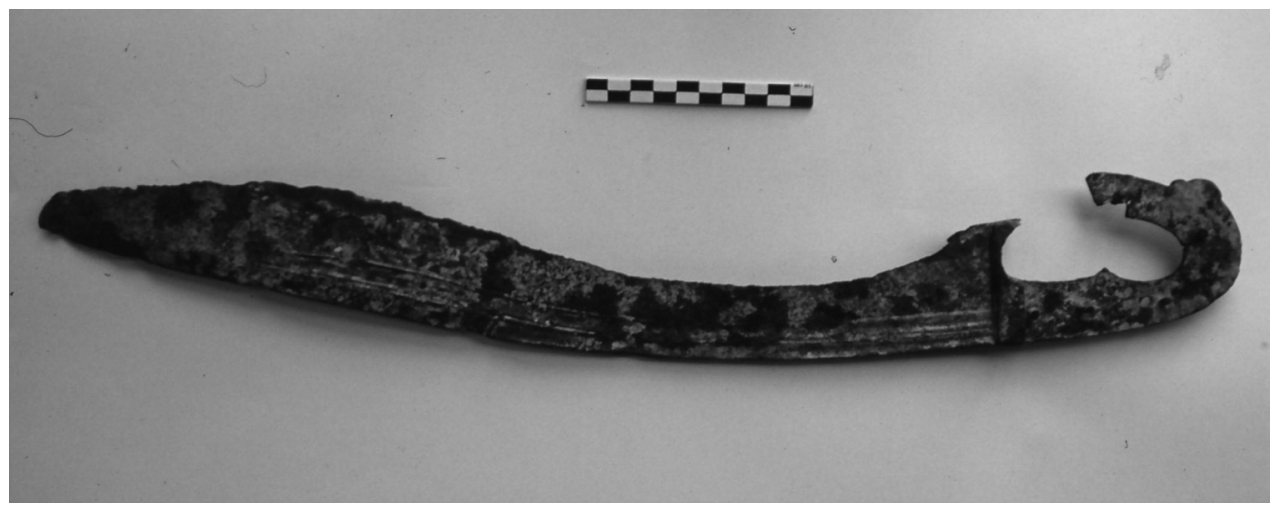

Fig. 10. Típica falcata ibérica (Almedinilla, Córdoba).

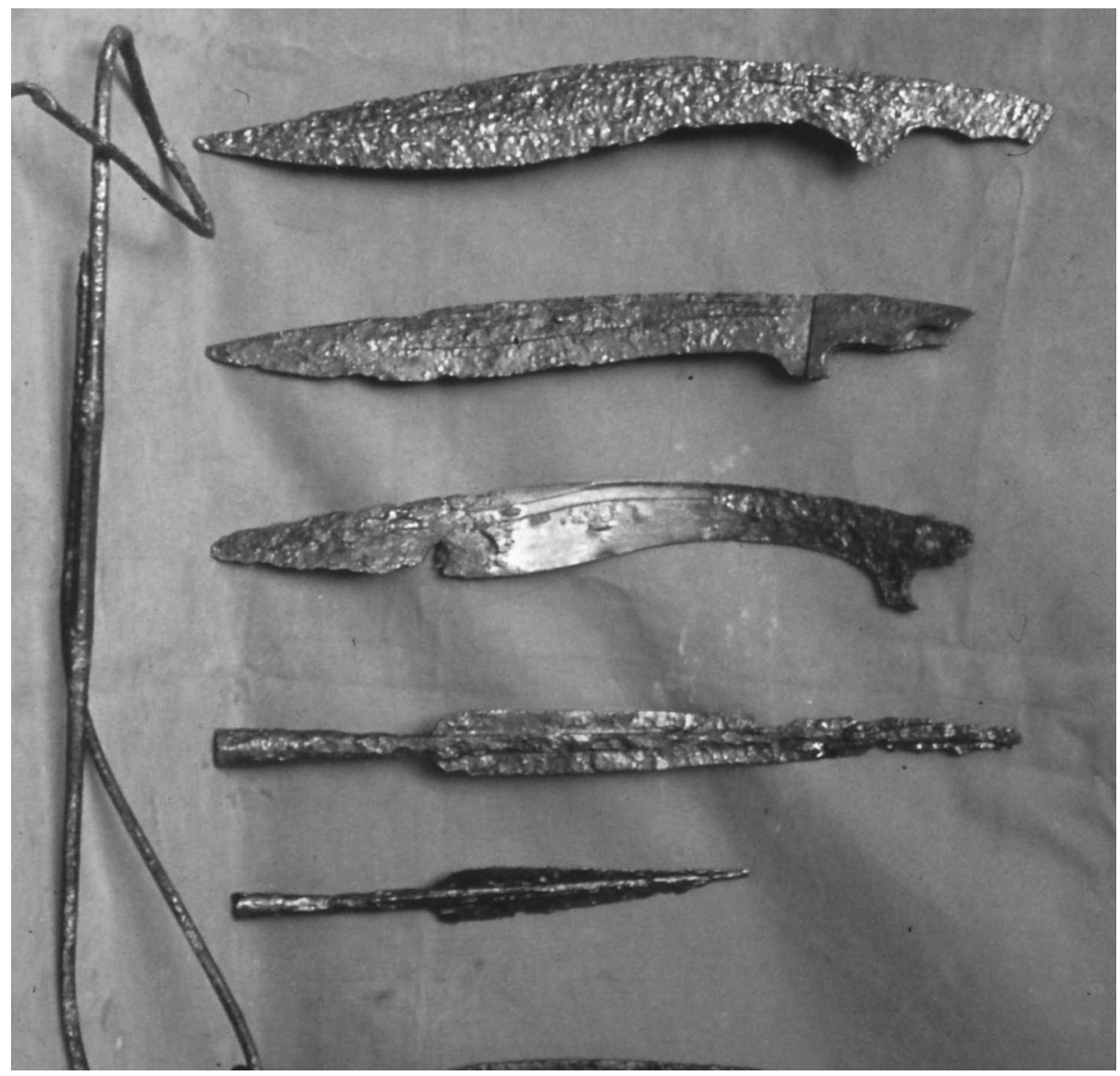

Fig. 11. Falcatas, puntas de lanza y soliferreum ibéricas. 


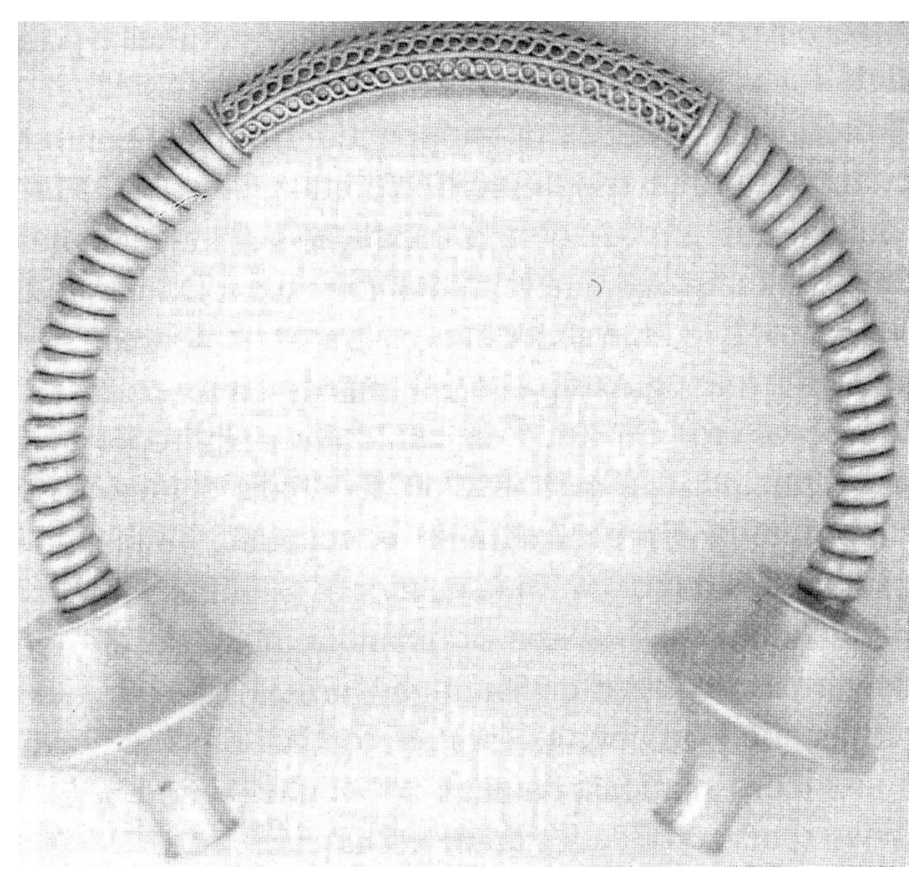

Fig. 12. Torques galaico de oro (Museo do Castro do Viladonga, Lugo).

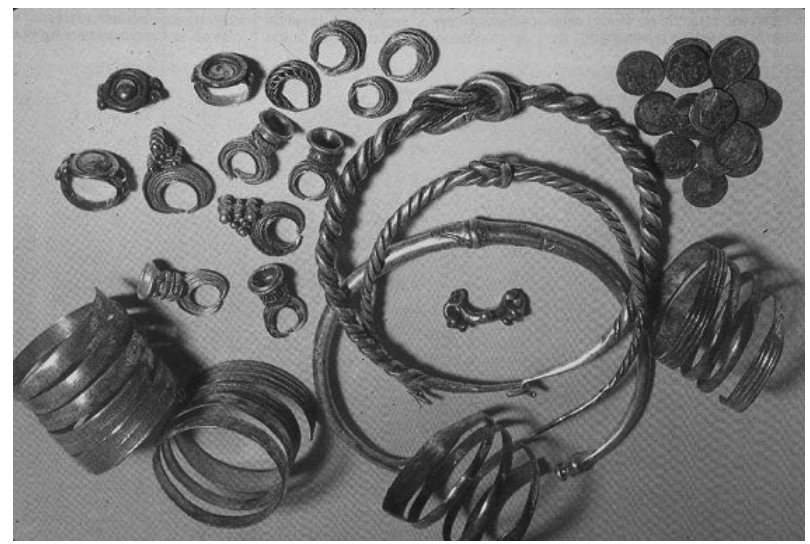

Fig. 13. Joyas (brazaletes, pulseras y anillos).

Fig. 14. Estatua de guerrero galaico-lusitano (Galicia).

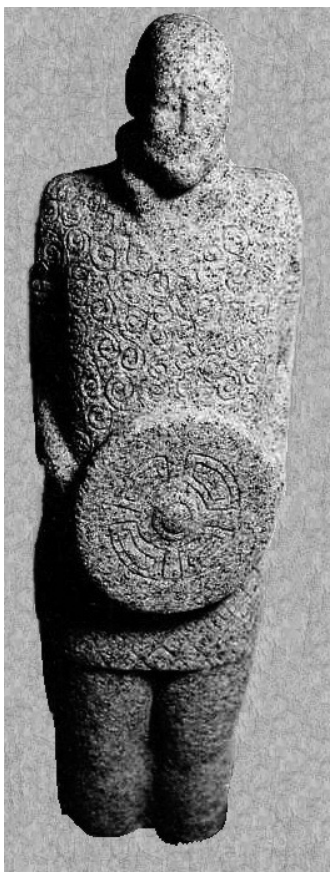


Fig. 15. Estatua de Viriato de M. Benlliure, Viseu (Portugal).
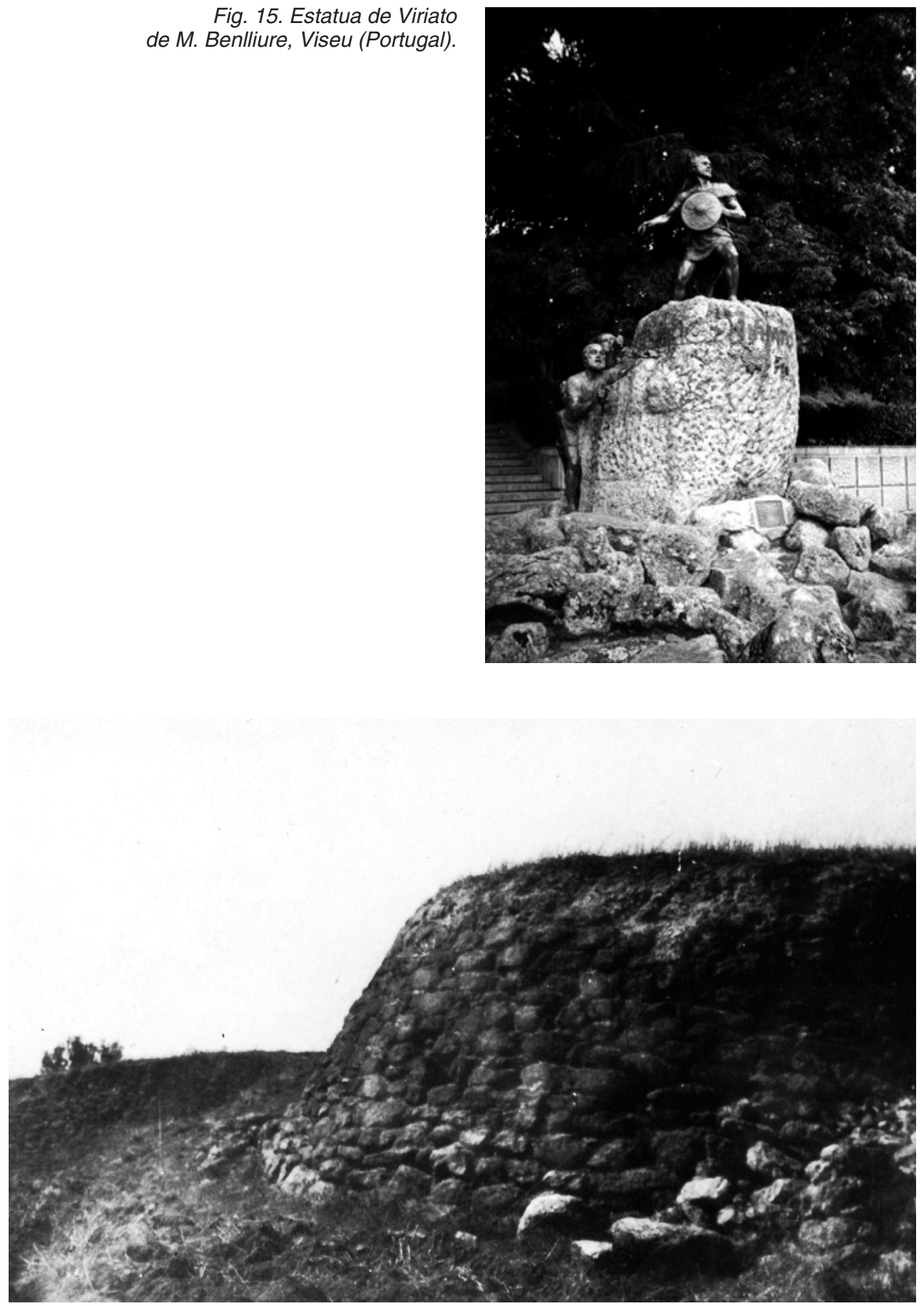

Fig. 16. Torres de la muralla de Urso (Osuna). 


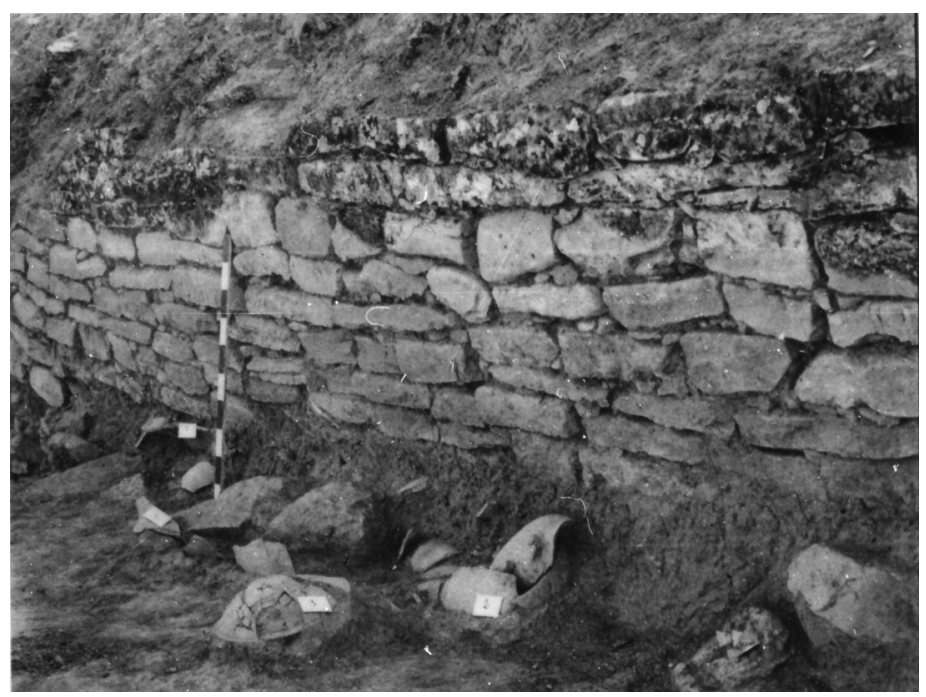

Fig. 17. Muralla

romana de Cástulo.

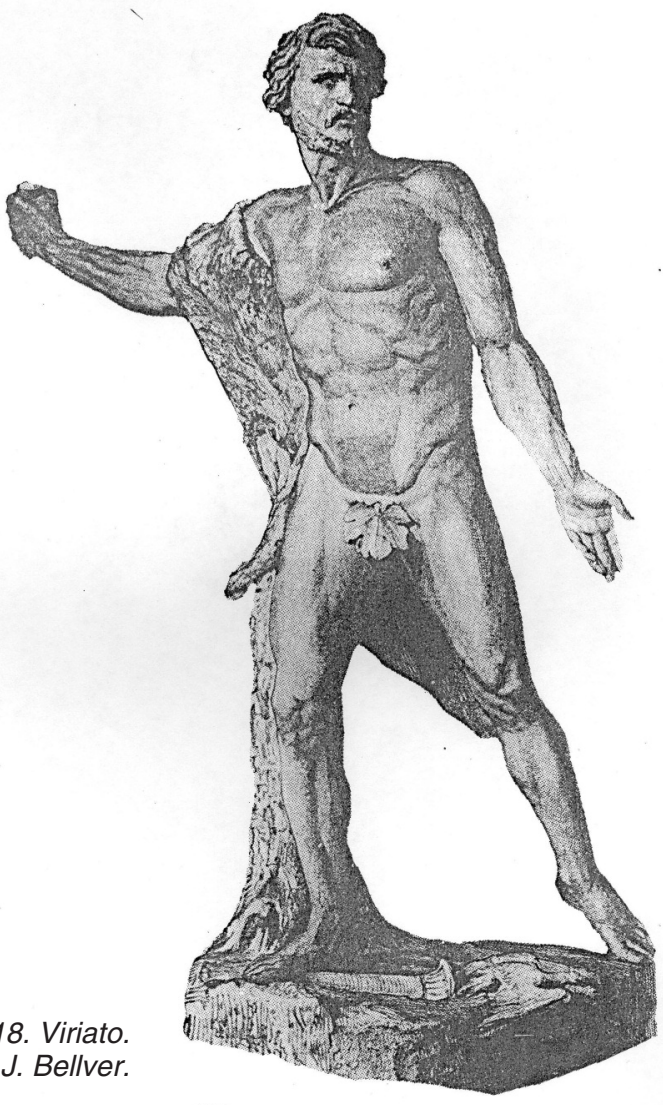

Dibujo de J. Bellver.

(c) UNED. Espacio, Tiempo y Forma

Serie II, Historia Antigua, t. 24, 2011 
Fig. 19. Estatua de Viriato en Zamora.
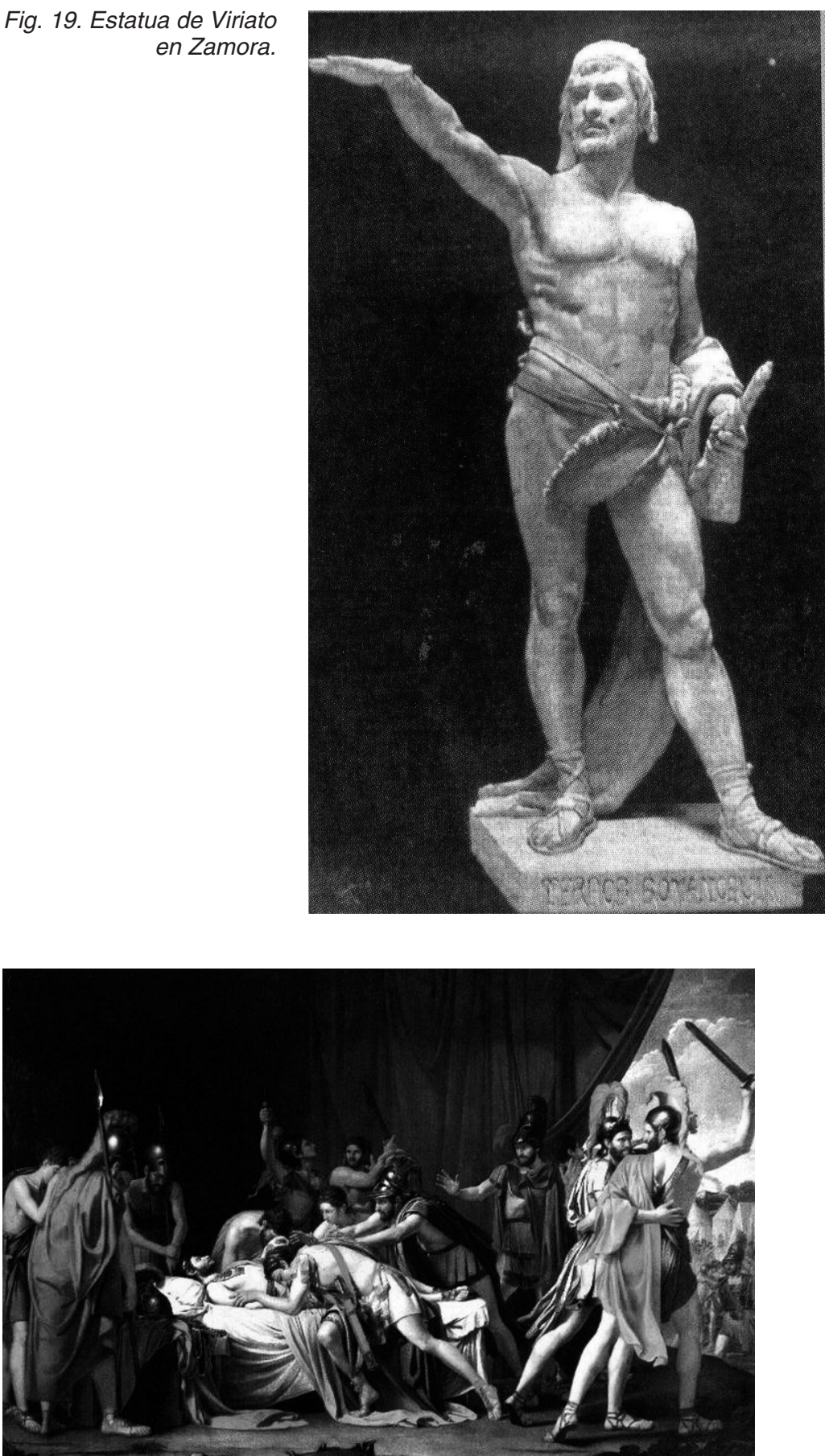

Fig. 20. La muerte de Viriato de José Madrazo. 